\title{
Freshwater bivalve shells as hydrologic archives in the Congo Basin
}

\author{
Zita Kelemen $^{\mathrm{a}, *}$, David P. Gillikin ${ }^{\mathrm{b}}$, Alberto V. Borges ${ }^{\mathrm{c}}$, Ernest Tambwe ${ }^{\mathrm{d}}$ \\ Alfred Toengaho Sembaito ${ }^{\mathrm{d}}$, Taylor Mambo ${ }^{\mathrm{d}}$, José Nlandu Wabakhangazi ${ }^{\mathrm{e}}$ \\ Athanase Yambélé ${ }^{\mathrm{f}}$, Yannick Stroobandt ${ }^{\mathrm{a}}$, Steven Bouillon ${ }^{\mathrm{a}}$ \\ ${ }^{a}$ Department of Earth \& Environmental Sciences, KU Leuven, Celestijnenlaan 200 E, B-3001 Leuven, Belgium \\ ${ }^{\mathrm{b}}$ Department of Geology, Union College, 807 Union St., Schenectady, NY 12308, USA \\ ${ }^{\mathrm{c}}$ Chemical Oceanography Unit, University of Liége, Allée du 6 Août, 17, B-4000 Liége, Belgium \\ ${ }^{\mathrm{d}}$ Centre de Surveillance de la Biodiversité, Université de Kisangani, The Democratic Republic of the Congo \\ ${ }^{\mathrm{e}}$ Congo Atomic Energy Commission, Kinshasa, The Democratic Republic of the Congo \\ ${ }^{\mathrm{f}}$ Service de l'Agrométéorologie et de Climatologie, Direction de la Météorologie Nationale, Bangui, Central African Republic
}

Received 26 June 2020; accepted in revised form 15 May 2021; Available online 20 May 2021

\begin{abstract}
We test the applicability of bivalve shell oxygen isotope composition to reconstruct hydrological dynamics in four riverine sites in the Congo River basin. Twenty-three specimens from the Unionoida order were collected from locations where longterm discharge data are available, and in situ measurements and water samples were collected over several years. Due to the highly variable (species-specific) shell morphology, various sampling techniques were used to analyze the shell sections; however, every specimen recorded the seasonality of the host water oxygen stable isotope composition $\left(\delta^{18} \mathrm{O}_{\mathrm{w}}\right)$ in its $\delta^{18} \mathrm{O}_{\text {shell }}$ record. Discharge data showed an inverse relationship with $\delta^{18} \mathrm{O}_{\mathrm{w}}$ values, which was well described with a logarithmic fit. An exception was the Kasai River, where the $\delta^{18} \mathrm{O}_{\mathrm{w}}$ record shows an additional peak occurring during the high discharge period, which renders the discharge- $\delta^{18} \mathrm{O}_{\mathrm{w}}$ relationship more complex than in the other systems investigated. Low ratios of maximum to minimum discharge $\left(\mathrm{Q}_{\max } / \mathrm{Q}_{\min }\right)$ were found to result in a low $\delta^{18} \mathrm{O}_{\mathrm{w}}$ amplitude, which was reflected as low $\delta^{18} \mathrm{O}_{\text {shell }}$ variability. The Congo and Kasai rivers had $\mathrm{Q}_{\max } / \mathrm{Q}_{\min }$ ratios $\sim 2$ to 2.5 , while the Oubangui showed a much higher $\mathrm{Q}_{\max } / \mathrm{Q}_{\min }(\sim 19)$. Shells correspondingly showed a large $\delta^{18} \mathrm{O}_{\text {shell }}$ range (amplitude between 2.4 and 5.0\%) for individual Oubangui shells, and lower amplitude for other sites (1.0 to 2.2\%o). Thus, shells have a high resolving power to be used to record hydrological variability, since long-term changes in precipitation pattern, discharge, land-use change, or other hydrological changes have an influence on $\delta^{18} \mathrm{O}_{\mathrm{w}}$ values. Shells with wide range of $\delta^{18} \mathrm{O}$ values reflect high seasonal variability in rivers, while shells with lower $\delta^{18} \mathrm{O}$ amplitude correspond to sites with more steady river conditions over the year. Our study illustrates that fossil shell $\delta^{18} \mathrm{O}$ values could indicate $\mathrm{Q}_{\max } / \mathrm{Q}_{\min }$ values in ancient African river systems.
\end{abstract}

(C) 2021 Elsevier Ltd. All rights reserved.

Keywords: Oxygen isotopes; Etheria; Chambardia; Aspatharia; Oubangui; Kasai; Congo; Hydrologic archive; River discharge; Seasonality

\section{INTRODUCTION}

* Corresponding author.

E-mail address: zita.kelemen@kuleuven.be (Z. Kelemen).

Hydrological processes vary spatially and temporally and are particularly affected by the changing climate. The importance of the water cycle is evident in its interaction 
with biogeochemical cycles in various hydrological processes (Brunner et al., 2017), whereby the distribution of stable oxygen isotopes $\left(\delta^{18} \mathrm{O}\right)$ has been shown to be an important proxy. Changes influencing precipitation have a cascading effect on biogeochemical cycles, affecting river recharge. To trace such changes, oxygen and hydrogen stable isotope measurements in river water are commonly employed, which can be further linked to catchment water balance and river recharge sources on regional- and larger scales (Gat, 1996). Climatic and geographical factors are mainly responsible for variations in the water cycle, however, anthropogenic influences are increasing in importance (Gorski et al., 2015; Jameel et al., 2016). Precipitation seasonality and high frequency variability are important aspects of the water cycle, however many terrestrial proxies of precipitation cannot be easily resolved seasonally (such as lake cores or speleothems). Freshwater bivalves on the other hand have been shown to be promising highresolution hydrologic proxies (e.g., Dettman et al., 2001; Dettman and Lohmann, 2000), but have not been routinely utilized in regions with sparse hydrological monitoring such as tropical Africa.

With a low degree of human influence ( $\sim 19$ inhabitants/ $\mathrm{km}^{2}$ ), the Congo Basin is an ideal region where the impact of climate change can be distinguished from land use changes or natural variations. The hydrological and meteorological data collection network in the Congo Basin is sparse and very few hydrological stations are still operational, with only a handful of sites for which long-term data (i.e. spanning the past century) are available (Laraque et al., 2001; Alsdorf et al., 2016). Given the basin's large area $\left(3.7 \times 10^{6} \mathrm{~km}^{2}\right.$ at Kinshasa) it has a very complex climate gradient and plays an important role in the regional and even global climate. Hosting the largest tropical forest on the continent, the Congo Basin has a strong impact on temperature and rainfall (Lawrence and Vandecar, 2015), and as the second largest river basin globally in terms of catchment size and discharge, its freshwater and nutrient delivery to the Atlantic Ocean is significant (Mariotti et al., 1991; Laraque et al., 2009). However, in the absence of longterm hydrological records, the temporal evolution of the basin remains difficult to constrain. Thus, proxies are needed to replace these missing hydrological data.

Numerous studies have shown the potential of freshwater bivalve shells as archives for precipitation patterns, climatic conditions or discharge (Abell et al., 1996; Dettman et al., 1999; 2001; 2004; Kaandorp et al., 2005; Versteegh et al., 2011; Kelemen et al., 2017). The sequentially precipitated shell carbonate in bivalves stores information about geochemical and environmental conditions of the water where the specimen lives, and this information can be restored on a time axis if the moment of death is known. It has been previously established that the majority of freshwater bivalves precipitate their shell in oxygen isotope equilibrium with the ambient water (Dettman et al., 1999; Goewert et al., 2007; Kelemen et al., 2017; Goodwin et al., 2019). Moreover, oxygen stable isotope ratios in the river water are directly related to evaporation, precipitation, the amount of precipitation, or a change in vapor source (Dansgaard, 1964; Mook and Rozanski, 2000), and $\delta^{18} \mathrm{O}_{\mathrm{w}}$ can often be related to river discharge (Versteegh et al., 2011; Kelemen et al., 2017). A recent global synthesis by Pfister et al. (2019) expanded on the work of Kohn and Dettman (2007) and confirmed that average freshwater bivalve shell $\delta^{18} \mathrm{O}$ values can explain $95 \%$ of the variation observed in average river $\delta^{18} \mathrm{O}_{\mathrm{w}}$ values, providing a broad-scale assessment of the applicability of this proxy across contrasting freshwater systems. However, by focusing on average $\delta^{18} \mathrm{O}$ values, the information held in the high-resolution measurements of $\delta^{18} \mathrm{O}$ values across the shell growth axis is not fully exploited. Here, we move the focus to the seasonal variability of $\delta^{18} \mathrm{O}_{\mathrm{w}}$ values and how that is reflected in shell $\delta^{18} \mathrm{O}$ records at various locations within the Congo Basin.

Freshwater bivalves from two tropical rivers (Niger and Oubangui River) have shown potential in accurately recording water stable oxygen isotope values $\left(\delta^{18} \mathrm{O}_{\mathrm{w}}\right)$ and in reconstructing (low) discharge values (Kelemen et al., 2017). However, these two rivers characteristically have (i) a high ratio between high and low discharge $\left(\mathrm{Q}_{\max } / \mathrm{Q}_{\min }\right.$ is over 10 for the Oubangui River and over 17 for the Niger River), and (ii) a clear (logarithmic) correlation between Q and $\delta^{18} \mathrm{O}_{\mathrm{w}}$. The question is then how widely applicable this approach is in the Congo Basin, considering that the hydrological regimes differ strongly across the basin, culminating in a very low $\mathrm{Q}_{\max } / \mathrm{Q}_{\min }$ for the lower Congo River, because contributions from northern and southern tributaries cancel each other out (Runge, 2007).

The major objectives of this study were (i) to examine shell $\delta^{18} \mathrm{O}$ records in different catchment areas, (ii) to compare measured shell $\delta^{18} \mathrm{O}$ records with available water discharge and $\delta^{18} \mathrm{O}_{\mathrm{w}}$ records, and (iii) to test to which extent bivalves can be used to reconstruct river water $\delta^{18} \mathrm{O}$ seasonality across a diverse river system such as the Congo Basin.

\section{MATERIALS AND METHODS}

\subsection{Study sites}

The Congo Basin is located in central Africa, and the catchment area is almost equally distributed across the northern and southern hemisphere (Fig. 1). The annual rainfall ranges between 700 and $2400 \mathrm{~mm}$, increasing from the northern and southern borders towards the central equatorial part of the basin, with highest rainfall during November and December (Nicholson, 2000). In general, the Congo Basin has two wet and two dry seasons, although the north equatorial part has no dry season at all. Its distribution across both hemispheres results in a relatively constant river flow during the year in the lower Congo River at Kinshasa, since at any given period certain regions within the basin experience abundant rainfall (Fig. 2). The nearly $4700 \mathrm{~km}$ long Congo River can be divided into three sections: upper, middle and lower Congo. The Upper Congo River stretches from the source in the southeastern part of the Democratic Republic of Congo (DRC), where the complex set of headwaters flow through numerous rapids and falls into the Lualaba River, until the Wagenia Falls near Kisangani, where the river becomes formally known as the Congo River (Runge, 2007). 


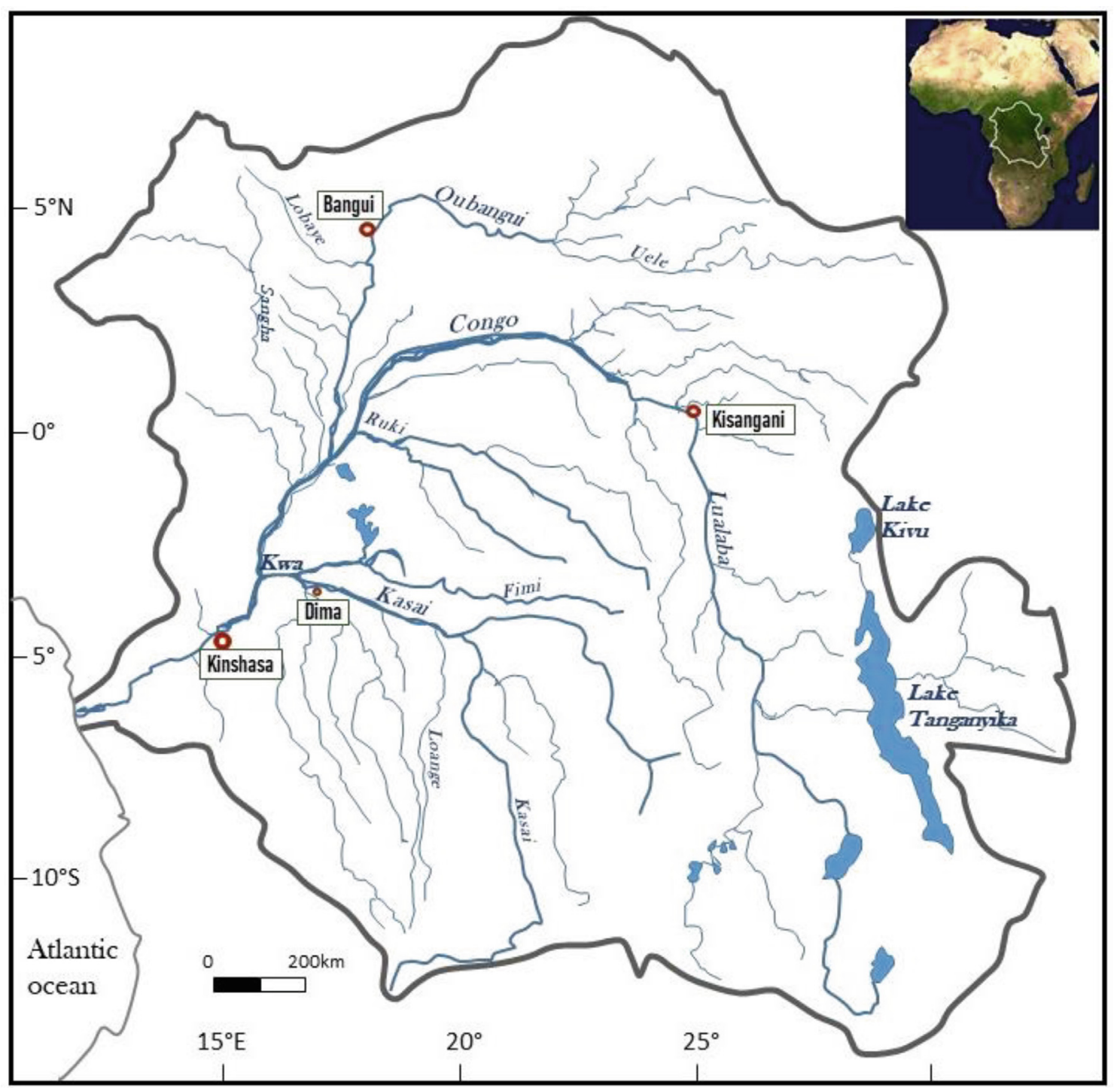

Fig. 1. Map of the Congo Basin with a general overview of the hydrological network. Sampling sites discussed in this chapter are indicated in white boxes.

The middle section is characterized by generally lower water velocities due to the widening of the river channel and traverses the rainforests in the central depression in the Congo Basin, known as the "Cuvette Centrale Congolaise". The major tributaries (Oubangui, Ruki, Sangha, Kasai) join at this part of the Congo River upstream of the Malebo Pool, the lake-like widening in the Congo River above Kinshasa/Brazzaville. The Cuvette Centrale is a flat area, home to the World's largest swamp forest; within the basin the tributaries drain different physiographic units including the Asande Rise in the north, the Tékés plateau in the west and the Kasai shield in the south (Laraque et al., 2009; Runge, 2007). The lower Congo starts after the Malebo Pool and reaches the Atlantic Ocean through a set of rapids which results in the largest falls by flow rate (Inga Falls) on the continent.

Water and shell samples were collected at four locations within the Congo Basin (Fig. 1), each with long-term dis- charge records. Two locations were on the main stem of the Congo River (Kisangani and Kinshasa); one site was on the Oubangui River (at Bangui, Central African Republic) and one on the Kasai River (at Dima).

Upper Congo River (Kisangani). Kisangani is located in the central part of the DRC, at the point where the Lualaba River turns west. Below the Wagenia Falls, the Lualaba becomes the Congo River. Upstream of Kisangani the Upper Congo rapids form the boundary between the upper and middle section of the Congo River. The central basin is covered with rainforest, there is almost no dry season and the annual rainfall can reach $2400 \mathrm{~mm}$ (Bultot, 1971). This region is characterized by a bimodal discharge regime (Fig. 2).

Oubangui (Bangui). The Oubangui is the largest right bank tributary of the Congo River. The vegetation cover in the south catchment of the Oubangui is dominated by tropical rainforests with yearly precipitation of 

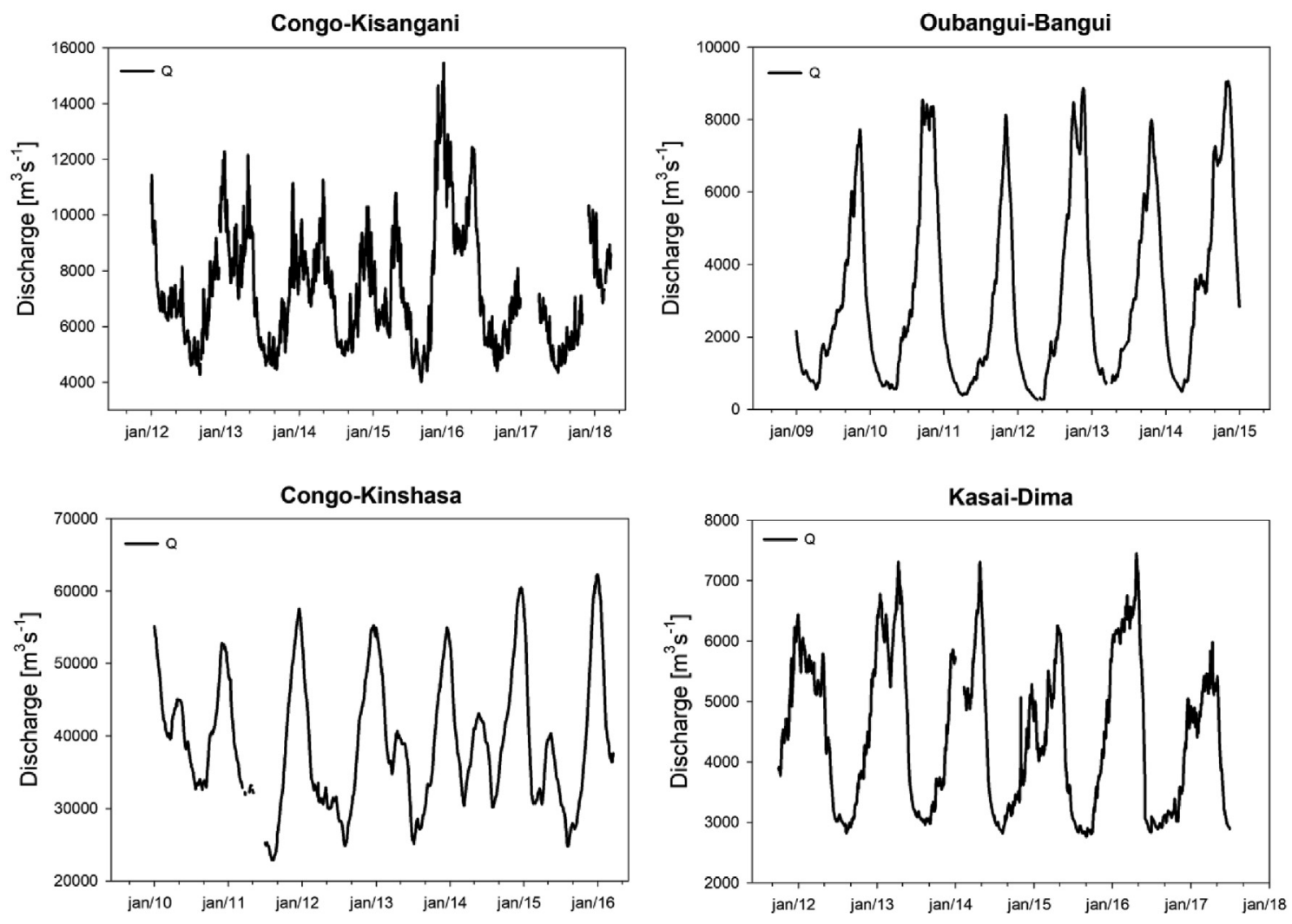

Fig. 2. Daily discharge values at the four monitoring stations (see text for data sources).

$1600-1800 \mathrm{~mm}$; towards the north, the vegetation gradually changes into wooded savannah and more open savannah, with decreasing yearly precipitation (down to $700 \mathrm{~mm} \mathrm{year}^{-1}$ ) (Calléde et al., 2010). The alternating wet and dry seasons result in a unimodal discharge regime at Bangui (Fig. 2), with high flow between September and December, and low flow after the dry season, during March and April (Bouillon et al., 2012; Kelemen et al., 2017).

Kasai (Dima). The Kasai River is the main left bank tributary of the Congo River and drains nearly one third of the Congo Basin in the southern hemisphere. The northern edge of the Kasai Basin is near the equator, with abundant rainfall which gradually decreases to the south. The alternating dry and wet season results in 1200-1750 mm precipitation annually, with a mainly bimodal partition. The Kasai catchment is characterized by open savannah woodland.

Lower Congo River (Kinshasa). Kinshasa is located on the left bank of the lower Congo (DRC), close to the outflow of the Malebo pool, the major widening on the Congo River. The Malebo pool is around $28 \mathrm{~km}$ wide, with many sand islands, and likely is the remnant of a lake in the western Congo Basin, which most is thought to have been formed when the Atlantic Rise dammed the course of the river, creating a large lake (Runge, 2007). The bimodal discharge regime at Kinshasa is represented by a larger peak during November to January, when the wet season flow from the north arrives, and a smaller peak around May
(Fig. 2), when the discharge from southern tributaries increase the main stem flow (Coynel et al., 2005). There is a low discharge period during July and August, but the regular high rainfall in the Central Congo region lead to a low variation in flow throughout the year. The intraannual regime has been very stable for the last couple of decades: $\mathrm{Q}_{\max } / \mathrm{Q}_{\min } \sim 2$.

\subsection{Water sampling}

The four areas in the Congo Basin were monitored over different time periods and at different temporal resolution. Oubangui River water samples were taken fortnightly between March 2010 and November 2012 in Bangui (Central African Republic). Additional $\delta^{18} \mathrm{O}_{\mathrm{w}}$ and hydrogen isotope $\left(\delta^{2} \mathrm{H}_{\mathrm{w}}\right)$ data for the period between September 2009 and December 2018 were available from the IAEA (Global Network of Isotopes in Rivers (GNIR) database). Discharge was recorded since 1911 in Bangui, daily measurement data were provided by the Direction de la Métérologie Nationale. Congo River samples at Kisangani were collected biweekly since December 2012 (ongoing). Discharge was monitored since 1912. At Kinshasa, 16 months of monitoring data were collected between July 2011 and December 2012. Kinshasa has the longest existing hydrological time series on the Congo: daily discharge has been measured since 1903. From Kasai River monthly samples were collected for two years, between April 2015 and 
May 2017 at Dima (DRC). At Dima daily discharge measurements are available since 1909.

Water samples for stable isotope measurements were collected by a Niskin bottle or a custom - made flow - through sampling bottle submerged $0.5 \mathrm{~m}$ below the water surface from which $12 \mathrm{ml}$ Labco Exetainers or $8 \mathrm{ml}$ plastic vials were filled and shipped to KU Leuven for analysis. $\delta^{18} \mathrm{O}_{\mathrm{w}}$ was measured by equilibration with $\mathrm{CO}_{2}$ using an Elemental Analyzer Flash HT/EA coupled to a Thermo Delta V Advantage isotope ratio mass spectrometer (EA - IRMS) (described in Gillikin and Bouillon, 2007) or a Thermo GasBench coupled with Thermo Delta V Advantage IRMS (GB - IRMS). Water samples $(0.5 \mathrm{ml})$ were transferred into a $12 \mathrm{ml}$ Labco Exetainer, flushed with helium, and depending on the technique used, $200 \mu \mathrm{L}$ (for EA - IRMS) or $35 \mu \mathrm{L}$ (for GB - IRMS) of pure $\mathrm{CO}_{2}$ was added manually. Samples were equilibrated at ambient laboratory temperature (EA - IRMS) or at $25^{\circ} \mathrm{C}$ in the thermostated tray (GB - IRMS) for over $24 \mathrm{~h}$. Three in-house water standards were used to correct $\delta^{18} \mathrm{O}$ values. The long - term uncertainty for standard $\delta^{18} \mathrm{O}$ values was $\pm 0.1 \%$ o. Water samples collected from Oubangui River were analyzed or reanalyzed (samples collected between March 2010 and November 2012) by the IAEA (International Atomic Energy Agency, Vienna), where water samples were pipetted into $2 \mathrm{~mL}$ vials, and $\delta^{18} \mathrm{O}$ and $\delta^{2} \mathrm{H}$ values measured twice on different laser water isotope analyzers (Los Gatos Research or Picarro). Isotopic values were determined by averaging isotopic values from the last four out of nine injections, along with memory and drift corrections, with final normalization to the VSMOW/SLAP scales by using 2 - point lab standard calibrations, as fully described in Wassenaar et al. (2014) and Coplen and Wassenaar (2015). The long - term uncertainty for standard $\delta^{18} \mathrm{O}_{\mathrm{w}}$ values was $\pm 0.1 \%$ and $1.0 \%$ for $\delta^{2} \mathrm{H}_{\mathrm{w}}$ values. Water temperature in the monitored rivers was recorded when water samples were collected using YSI ProPlus probes.

\subsection{Shell collection and analyses}

Freshwater bivalves were collected at the four locations at various times. Shells were collected during the monitoring period at three locations, and after the monitoring period at one site (Kinshasa, in July 2015). Eleven shells from the Oubangui River were collected during four occasions: March 2011, February and November 2012, and March 2013 (Kelemen et al., 2017). Two shells from the Kasai River were collected in July 2015, shortly after the start of the monitoring period, and the six Kisangani shells are from February 2014 and January 2015. Bivalves were collected at various locations and times either through collaborators responsible for the water monitoring or through help from local fishermen. Our 23 freshwater bivalve specimens all belong to the Unionoida order, distributed between two superfamilies': the Unionoidea and Etherioidea (Yonge, 1962; Graf and Cummings, 2006). The Unionoidea superfamily is represented by four Coelatura specimens from the Unionidae family (Coelatura disciformis, Coelatura gabonensis, Coelatura leopoldvillensis), the other 19 specimens belong to the Etherioidea superfamily, with 15 specimens from the endemic Iridinidae family (Chambardia wissmanni, Aspatharia pfeifferiana, Mutela sp), while the five Etheria elliptica (the (African) freshwater oysters) belong to the Etheriidae family (Fig. 3, Table 1). All specimens discussed in this study were collected alive, which enabled data from the last period of growth (i.e., the collection date) to be aligned with the available water data. After sectioning one valve of each shell along the maximal growth axis, shell sections of a few mm thickness were mounted on glass slides, and serially sampled using a New Wave Micromill. Shells whose prismatic layer was thick enough (such as $C$. wissmanni shells from the Oubangui River) were serially sampled from the commissure to the umbo, with a $300 \mu \mathrm{m}$ diameter drill bit, achieving a sample resolution of 350 to $1000 \mu \mathrm{m}$. Depending on the size of the bivalve, this resulted in 30-260 samples per shell section and up to $80 \mu \mathrm{g}$ sample powder. In shells for which the prismatic layer thickness was not sufficient to drill holes, 400 to $800 \mu \mathrm{m}$ long lines were drilled with a $100 \mu \mathrm{m}$ drill bit. In E. elliptica specimens, subsequent parallel lines were milled across the entire thickness of the shells in cross section as the prismatic layer is not easily distinguishable from the other layers. With a $100 \mu \mathrm{m}$ drill bit lines of 2000 to $5000 \mu \mathrm{m}$ length and $80-150 \mu \mathrm{m}$ depth were milled, using the Micromill software to interpolate between the subsequent lines, to maintain 30 to $100 \mu \mathrm{m}$ thickness of the milled lines. Each powder microsample was collected separately in a $12 \mathrm{ml}$ Labco Exetainer, flushed with helium and reacted with $>100 \%$ phosphoric acid to produce carbondioxide gas. Samples were analyzed either at Union College or KU Leuven on a Thermo Delta V Advantage isotope ratio mass spectrometer coupled to a GasBench II. To reach isotope equilibrium, reaction was allowed for at least 3 hours at $50{ }^{\circ} \mathrm{C}$ or $>24$ hours at $25^{\circ} \mathrm{C}$. Data from each run were corrected using the regression method with LSVEC $\left(\delta^{18} \mathrm{O}=-26.7 \%\right.$, $\left.\delta^{13} \mathrm{C}=-46.6 \%\right)$, NBS $-18\left(\delta^{18} \mathrm{O}=-\right.$ $5.01 \%$ o, $\delta^{13} \mathrm{C}=-23.2 \%$ ), and NBS $-19\left(\delta^{18} \mathrm{O}=-2.2 \%\right.$, $\delta^{13} \mathrm{C}=+1.95 \%$ ) as standards, or using two in - house $\mathrm{CaCO}_{3}$ standards which were regularly calibrated against NBS - 19 and LSVEC and whose long - term standard deviations were better than $0.1 \%$. Both $\delta^{18} \mathrm{O}$ and $\delta^{13} \mathrm{C}$ values of shell aragonite are expressed relative to VPDB (Vienna Pee Dee Belemnite) scale, and have precisions of $<0.1 \%$ and are not corrected for the aragonite acid fractionation.

\section{RESULTS}

\subsection{River discharge, $\delta^{18} \mathrm{O}_{\mathrm{w}}$ and temperature}

Upper Congo River - The discharge (Q) regime at Kisangani shows regular double peak cycles, with the highest water levels in November-December and April-May (Fig. 2), which coincides with the movement of the tropical rain belt over the Congo Basin. During the monitoring period the highest discharge measured was $15,462 \mathrm{~m}^{3} \mathrm{~s}^{-1}$ in December 2015, while the lowest was $\sim 4000 \mathrm{~m}^{3} \mathrm{~s}^{-1}$ during August 2015. Water $\delta^{18} \mathrm{O}$ records showed a pronounced seasonality and accurately mirrored the discharge cycle: 

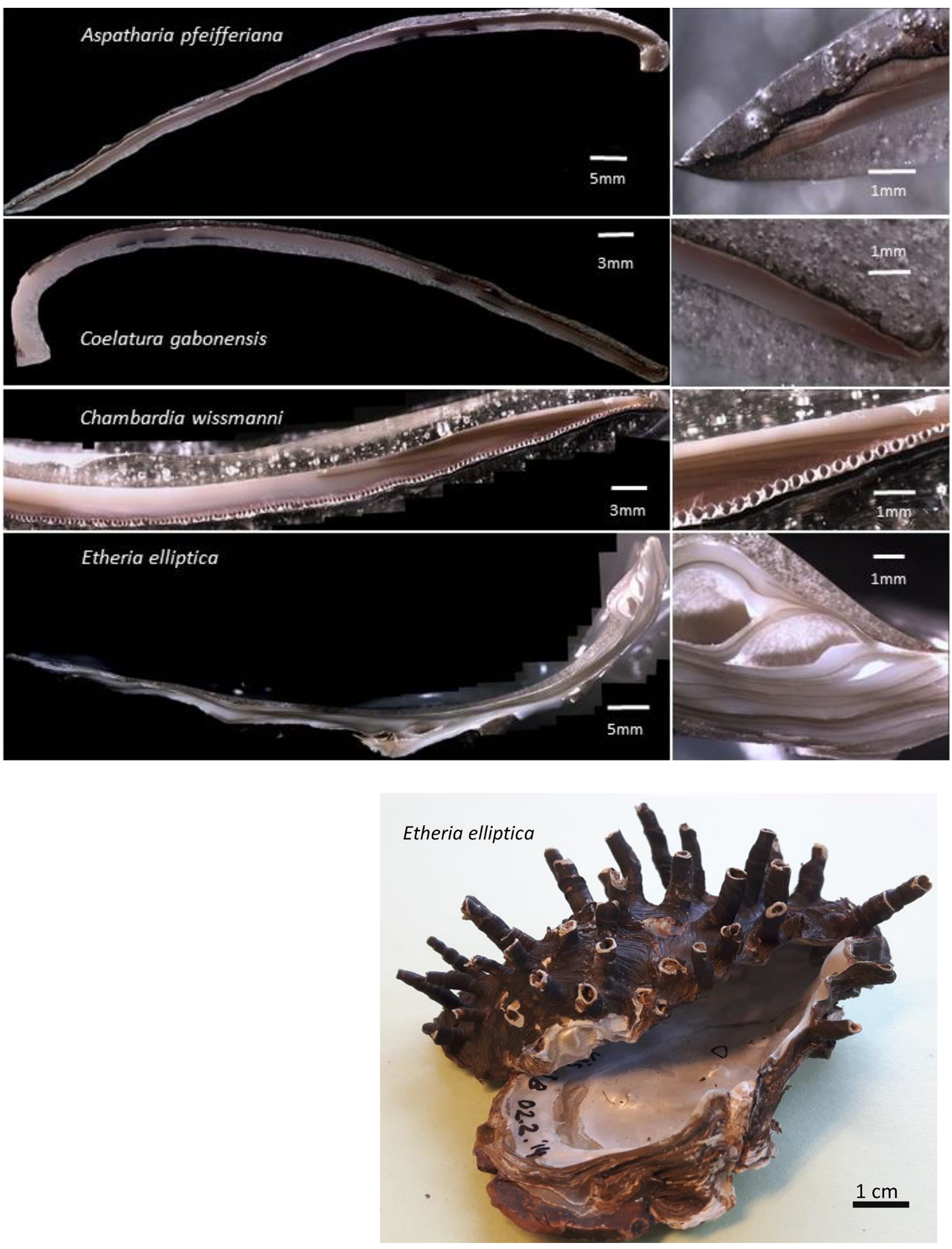

Fig. 3. Stereo-microscope images of four analyzed species. Upper photo set: collated images of thick sections of A. pfeifferiana, C. gabonensis, C. wissmanni (with drilled $(300 \mu \mathrm{m})$ holes), and Etheria elliptica shells (left column), with corresponding high resolution photos of a fragment of each shell (right column). Dark grey material is the epoxy the shells were embedded in. Bottom photo: an example of an E. elliptica shell. 
Table 1

$\delta^{18} \mathrm{O}_{\text {shell }}$ data (in permil) from all analyzed bivalves, including sample code with collection year, location and species.

\begin{tabular}{|c|c|c|c|c|c|c|}
\hline Location & Code & Species & Min & $\operatorname{Max}$ & Average & Range \\
\hline Kinshasa & $\begin{array}{l}\text { BV242(2015) } \\
\text { BV501(2015) } \\
\text { BV203(2015) } \\
\text { BV503(2015) }\end{array}$ & $\begin{array}{l}\text { Coelatura disciformis } \\
\text { Coelatura gabonensis } \\
\text { Aspatharia pfeifferiana } \\
\text { Mutela } \text { sp. }\end{array}$ & $\begin{array}{l}-4.7 \\
-4.7 \\
-4.5 \\
-4.2\end{array}$ & $\begin{array}{l}-3.2 \\
-3.2 \\
-2.7 \\
-2.4\end{array}$ & $\begin{array}{l}-3.8 \\
-3.8 \\
-3.6 \\
-3.3\end{array}$ & $\begin{array}{l}1.5 \\
1.6 \\
1.9 \\
1.8\end{array}$ \\
\hline Kisangani & $\begin{array}{l}\text { BV324(2015) } \\
\text { BV338(2015) } \\
\text { BV330(2015) } \\
\text { BV329(2015) } \\
\text { BV382_6(2014) } \\
\text { BV382_4(2014) }\end{array}$ & $\begin{array}{l}\text { Coelatura leopoldvillensis } \\
\text { Coelatura leopoldvillensis } \\
\text { Aspatharia pfeifferiana } \\
\text { Aspatharia pfeifferiana } \\
\text { Etheria elliptica } \\
\text { Etheria elliptica }\end{array}$ & $\begin{array}{l}-3.8 \\
-4.0 \\
-3.3 \\
-3.9 \\
-3.7 \\
-3.8\end{array}$ & $\begin{array}{l}-2.6 \\
-2.8 \\
-1.9 \\
-2.5 \\
-1.8 \\
-2.0\end{array}$ & $\begin{array}{l}-3.0 \\
-3.3 \\
-2.7 \\
-3.1 \\
-2.6 \\
-2.7\end{array}$ & $\begin{array}{l}1.2 \\
1.2 \\
1.4 \\
1.4 \\
1.9 \\
1.8\end{array}$ \\
\hline Kasai (Dima) & $\begin{array}{l}14 \mathrm{~B}(2015) \\
17 \mathrm{~B}(2015)\end{array}$ & $\begin{array}{l}\text { Etheria elliptica } \\
\text { Etheria elliptica }\end{array}$ & $\begin{array}{l}-4.9 \\
-5.7\end{array}$ & $\begin{array}{l}-3.9 \\
-3.5\end{array}$ & $\begin{array}{l}-4.3 \\
-4.3\end{array}$ & $\begin{array}{l}1.0 \\
2.2\end{array}$ \\
\hline Oubangui (Bangui) & $\begin{array}{l}\text { 1A(2013) } \\
4 \mathrm{~A}(2013) \\
\text { 2B(2013) } \\
\mathrm{BB} 6(2012) \\
\text { 3B(2012) } \\
\mathrm{B} 23(2011) \\
\mathrm{B} 11(2011) \\
\mathrm{B} 17(2011) \\
\mathrm{B} 16(2011) \\
\text { DPG92(2011) } \\
\text { DPG91(2011) }\end{array}$ & $\begin{array}{l}\text { Chambardia wissmanni } \\
\text { Chambardia wissmanni } \\
\text { Chambardia wissmanni } \\
\text { Chambardia wissmanni } \\
\text { Chambardia wissmanni } \\
\text { Chambardia wissmanni } \\
\text { Chambardia wissmanni } \\
\text { Chambardia wissmanni } \\
\text { Chambardia wissmanni } \\
\text { Etheria elliptica } \\
\text { Etheria elliptica }\end{array}$ & $\begin{array}{l}-5.1 \\
-4.5 \\
-3.9 \\
-4.7 \\
-3.5 \\
-3.3 \\
-3.4 \\
-3.2 \\
-3.7 \\
-4.9 \\
-3.1 \\
\end{array}$ & $\begin{array}{l}-0.1 \\
-0.7 \\
0.2 \\
0.2 \\
-0.5 \\
-0.9 \\
-0.8 \\
-0.4 \\
-0.8 \\
-1.1 \\
-0.6\end{array}$ & $\begin{array}{l}-2.5 \\
-2.2 \\
-2.1 \\
-1.6 \\
-2.2 \\
-2.0 \\
-2.1 \\
-1.9 \\
-2.3 \\
-2.9 \\
-2.0\end{array}$ & $\begin{array}{l}5.0 \\
3.7 \\
4.1 \\
4.9 \\
3.0 \\
2.4 \\
2.6 \\
2.8 \\
3.0 \\
3.8 \\
2.5\end{array}$ \\
\hline
\end{tabular}

during high discharge, $\delta^{18} \mathrm{O}_{\mathrm{w}}$ values are low, and at the time of low(er) water levels, the $\delta^{18} \mathrm{O}_{\mathrm{w}}$ record moves towards higher values. The seven year long record shows an average $\delta^{18} \mathrm{O}_{\mathrm{w}}$ value of $-1.5 \pm 0.6 \%$ ( $\left.\mathrm{n}=161\right)$ and a range between $-3.3 \%$ and $0.0 \%$. Water temperatures varied between $23.3{ }^{\circ} \mathrm{C}$ and $30.3{ }^{\circ} \mathrm{C}$ (average $27.0 \pm 1.0{ }^{\circ} \mathrm{C} ; \mathrm{n}=139$; Fig. 4).

Oubangui $-\delta^{18} \mathrm{O}_{\mathrm{w}}$ values, water temperature and discharge for the Oubangui River were presented in Kelemen et al. (2017). At Bangui, a single peak discharge can be observed, typical for a transitional tropical regime. During the monitoring period the discharge varied between $265 \mathrm{~m}^{3} \mathrm{~s}^{-1}$ and $8868 \mathrm{~m}^{3} \mathrm{~s}^{-1}$. Water temperature showed a low variability, and ranged between 25.1 and $31.5{ }^{\circ} \mathrm{C}$ (average $28.6 \pm 1.2{ }^{\circ} \mathrm{C}$ ), however the lowest values were only very short term excursions (lasted less than a month). Without these exceptions, the temperature remained above $27{ }^{\circ} \mathrm{C}$. $\delta^{18} \mathrm{O}_{\mathrm{w}}$ values from the Oubangui River showed the highest range among the studied rivers $(6.3 \%)$, with values between $-3.7 \%$ and $+2.6 \%$ with an average of $-0.7 \%$ o ( $\mathrm{n}=163$; Fig. 4).

Kasai -The river at Dima exhibits a unimodal discharge regime with highest water levels during April-May. A moderate increase in discharge during December-January precedes the peak values, and in some years it appears more like a twin-peak hydrograph (Fig. 2). The discharge during the monitoring period varied between 2764 and $7452 \mathrm{~m}^{3} \mathrm{~s}^{-1}$. Variations in $\delta^{18} \mathrm{O}_{\mathrm{w}}$ values were low, less than $2 \%$, between 2015 and 2017. The lowest $\delta^{18} \mathrm{O}_{\mathrm{w}}$ value measured was $-4.1 \%$, while the highest was $-2.5 \%$ (average $-3.3 \pm 0.4$ $\% ; \mathrm{n}=26)$. The seasonality of the $\delta^{18} \mathrm{O}_{\mathrm{w}}$ record is pronounced, however the inverse relationship between $\delta^{18} \mathrm{O}_{\mathrm{w}}$ and $\mathrm{Q}$ is interlaced with an additional increase of $\delta^{18} \mathrm{O}_{\mathrm{w}}$ values during high discharge periods. Water temperature variations are low as well, ranging between $26^{\circ} \mathrm{C}$ and $29.3^{\circ} \mathrm{C}$, on average $28.1 \pm 0.9^{\circ} \mathrm{C}(\mathrm{n}=26$; Fig. 4$)$.

Lower Congo River - The Congo River at Kinshasa shows a bimodal hydrograph, with a large peak during December and a smaller peak in May (Fig. 2). The maximum value during the monitoring period was measured in December $2011\left(57569 \mathrm{~m}^{3} \mathrm{~s}^{-1}\right)$ and the lowest discharge value in August $2011\left(22864 \mathrm{~m}^{3} \mathrm{~s}^{-1}\right)$. The relatively short term oxygen isotope record at Kinshasa shows an inverse relationship with discharge, with lowest values during high water level. The $\delta^{18} \mathrm{O}_{\mathrm{w}}$ values range between $-3.1 \%$ and $-1.3 \%$ with an average of $-2.3 \pm 0.5 \%$ ( $\mathrm{n}=29)$. Water temperature varied between $26.0^{\circ} \mathrm{C}$ and $29.0{ }^{\circ} \mathrm{C}$, with an average of $27.6 \pm 1.0^{\circ} \mathrm{C}(\mathrm{n}=30)$.

The full set of river data used in this study is available as an electronic supplement.

\subsection{Predicted $\delta^{18} \mathrm{O}$ profiles (model shells)}

A "model shell" $\delta^{18} \mathrm{O}$ profile (Kelemen et al., 2017) was calculated based on measured $\delta^{18} \mathrm{O}_{\mathrm{w}}$ values and water temperature for each site using an equation for biogenic aragonite oxygen isotope fractionation, modified by Dettman et al. (1999) from the equation developed by Grossman and $\mathrm{Ku}$ (1986).

$1000 \ln (\alpha)=2.559\left(10^{6} T^{-2}\right)+0.715$

where $\mathrm{T}$ is the water temperature in Kelvin and $\alpha$ is the fractionation between water and aragonite described by the following equation: 


$$
\begin{aligned}
\alpha_{\text {(aragonite-water })=} & \left(1000+\delta{ }^{18} \mathrm{O}_{\text {shell }}(\text { VSMOW }) /\right. \\
& \left.\left(1000+\delta{ }^{18} \mathrm{O}_{\mathrm{w}}(\text { VSMOW })\right)\right)
\end{aligned}
$$

The shell $\delta^{18} \mathrm{O}\left(\delta^{18} \mathrm{O}_{\text {shell }}\right)$ values (expressed relative to the VPDB scale) are converted to the VSMOW scale using the conversion factor 1.03091, determined by Coplen (1988). Ranges for the calculated model shells are listed in Table 2.

\subsection{Oxygen isotope profiles of shells}

General information about the analyzed specimens together with the $\delta^{18} \mathrm{O}$ data are summarized in Table 1 . Shells from all locations exhibited cyclicity in their $\delta^{18} \mathrm{O}$ profiles, showing that bivalves record seasonality of the host water, however differences were observed in the range of recorded $\delta^{18} \mathrm{O}$ data (Figs. S1, S2 and S3). The two shells from the Kasai River showed divergent $\delta^{18} \mathrm{O}_{\text {shell }}$ values, one of the Etheria specimens had the smallest range ( $\sim 1.0 \%)$ of all the analyzed shells, while the other specimen with a range of $2.2 \%$ (values between $-5.7 \%$ and $-3.5 \%$ ) exceeded the range of the calculated model shell for the Kasai River. $\delta^{18} \mathrm{O}_{\text {shell }}$ values from Kinshasa varied between $-4.7 \%$ and $-2.4 \%$ and shells from Kisangani ranged between $-4.0 \%$ and $-1.8 \%$, however the intra shell ranges at both sites were relatively low (see Table 1). The highest range in measured values, as well as the largest intra shell range was measured in the specimens from the Oubangui: $5.3 \%$ (from -5.1 to $0.2 \%$ ) and $5.0 \%$ (from -5.1 to $-0.1 \%$ ) , respectively. The full dataset of $\delta^{13} \mathrm{C}$ and $\delta^{18} \mathrm{O}$ data on the shell material presented in this study is available as an electronic supplement.
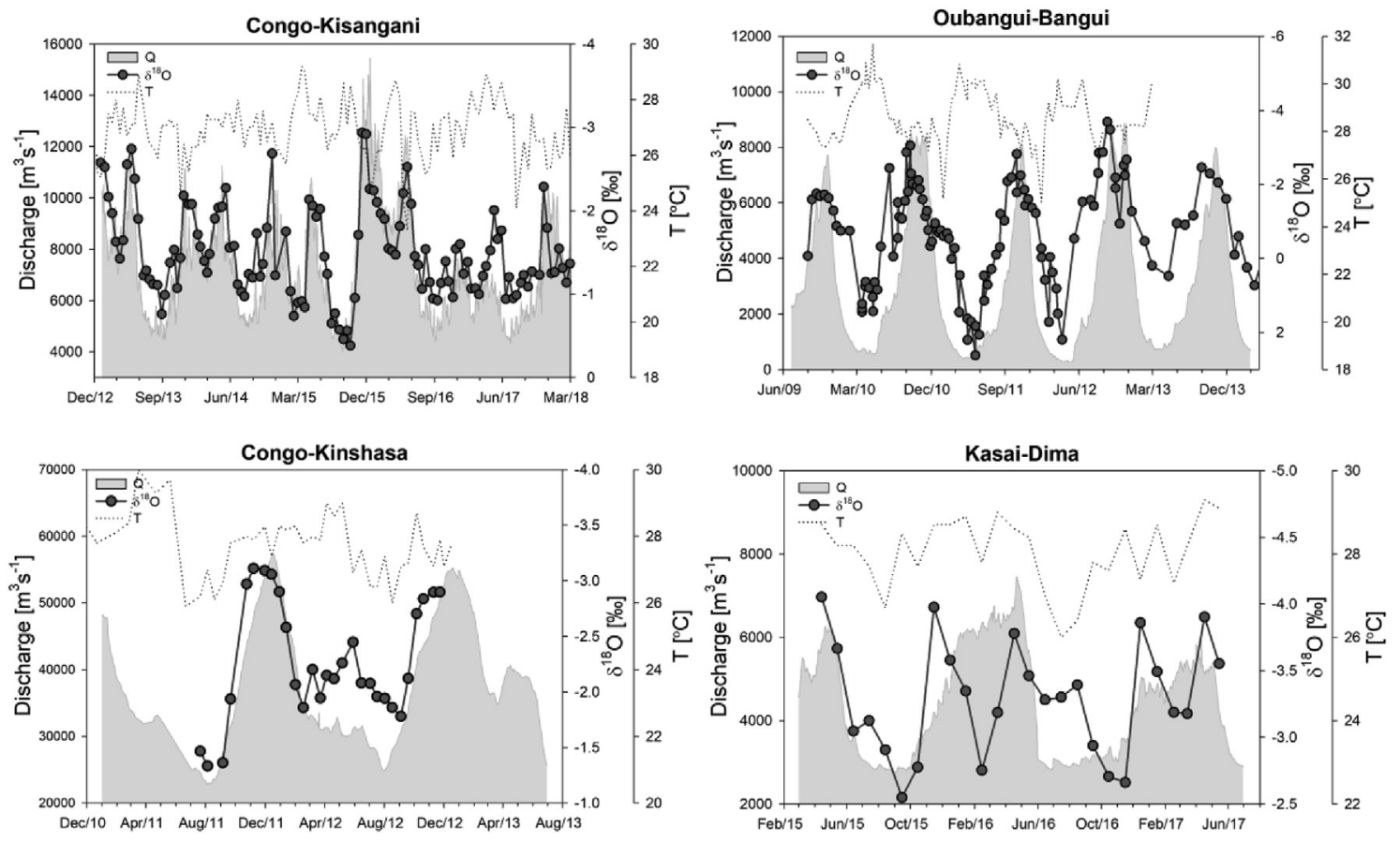

Fig. 4. Daily discharge data (grey area) plotted along with measured $\delta^{18} \mathrm{O}_{\mathrm{w}}$ values (black circles) and water temperature (dashed line) on a time axis for the monitored locations. 
et al., 2013; Wang et al., 2013; Henchiri et al., 2016; Lambert et al., 2016; Borges et al., 2015; 2019). In this study, we focus on riverine $\delta^{18} \mathrm{O}_{\mathrm{w}}$ values, from which important information about the source of the local water (precipitation and groundwater) can be derived, and which is also suitable to study changes over time (e.g.,Dettman and Lohmann, 2000; Fan and Dettman, 2009). At each of our study sites, the seasonality in discharge was mirrored by $\delta^{18} \mathrm{O}_{\mathrm{w}}$ variations. Measured $\delta^{18} \mathrm{O}_{\mathrm{w}}$ and $\mathrm{Q}$ values showed a clear inverse relationships in most rivers: during periods of high discharge, $\delta^{18} \mathrm{O}_{\mathrm{w}}$ values were low (representing the prevalence of ${ }^{18} \mathrm{O}$-depleted rainfall), while during low water conditions the $\delta^{18} \mathrm{O}_{\mathrm{w}}$ values become increasingly higher, likely reflecting more evaporative conditions and/or ${ }^{18} \mathrm{O}$ enriched precipitation (Figs. 4, S6 and S7) (c.f. Gremillion and Wanielista 2000; Kumar et al., 2019). The $\delta^{18} \mathrm{O}_{\mathrm{w}}$ - discharge relationship was well described by a logarithmic fit, with the exception of the Kasai River (Fig. 5) illustrating that this inverse relation is not always straightforward. Seasonal variations show that ${ }^{18} \mathrm{O}$-enrichment occurs systematically during both low-flow conditions (SeptemberOctober) and high-flow conditions (March) in the Kasai River (Fig. 4). This suggests that tributaries with high $\delta^{18} \mathrm{O}_{\mathrm{w}}$ values add significant volume to the Kasai River during the high discharge period in March. Indeed, several point measurements in the dense web of small tributaries along the Kasai River revealed that $\delta^{18} \mathrm{O}_{\mathrm{w}}$ values are up to $1 \%$ higher than in the main stem (Borges et al., 2019). The initial decrease in $\delta^{18} \mathrm{O}_{\mathrm{w}}$ during the rising stage coincided with high suspended matter loads, which points towards a high relative contribution of the Loange tributary during this period, since this left-bank tributary was found to show particularly high suspended matter concentrations during a basin-wide survey (Fig. S5, sampling campaign described in Borges et al., 2019). In the lower Congo River at Kinshasa, the bimodal discharge regime was clearly reflected in the $\delta^{18} \mathrm{O}_{\mathrm{w}}$ record (Fig. 4), with lower $\delta^{18} \mathrm{O}_{\mathrm{w}}$ values at the time when the increased flow arrives from the north (December flood). The more variable $Q$ record at Kisangani resulted in more scattered $\delta^{18} \mathrm{O}_{\mathrm{w}}$ data, nonetheless, the two variables are clearly linked (Figs. 4, 5). Daily variations in daily discharge at Kisangani were higher in comparison with the other locations, where the ascending and descending limbs of the daily discharge records are smoother. The dense network of small rivers, with numerous large tributaries joining the Congo-Lualaba river system within a forested area all contribute to the $\delta^{18} \mathrm{O}_{w}$ values, where there are clear short-term variations in $\mathrm{Q}$ and $\delta^{18} \mathrm{O}_{\mathrm{w}}$. The Lualaba river in the south traverses large

Table 2

Calculated model shell $\delta^{18} \mathrm{O}$ data (in $\%$ ) for the four locations, based on measured temperature data and water $\delta^{18} \mathrm{O}$ data.

\begin{tabular}{lllll}
\hline Location & Min & Max & Average & Range \\
\hline Kinshasa (Congo R.) & -4.6 & -2.6 & -3.7 & 2.1 \\
Kisangani (Congo R.) & -4.1 & -1.9 & -2.9 & 2.2 \\
Dima (Kasai R.) & -5.7 & -4.1 & -4.8 & 1.6 \\
Bangui (Oubangui R.) & -5.2 & 0.7 & -2.2 & 5.9 \\
\hline
\end{tabular}

wetland systems, such as the Upemba System and the Luama Swamps, where the first comprises about 50 shallow lakes (depth $\sim 3 \mathrm{~m}$ ) over $225 \mathrm{~km}$, and the latter cover $6,000 \mathrm{~km}^{2}$ of inundated area and spans over $130 \mathrm{~km}$ (Hughes and Hughes, 1992). These systems might have variable $\delta^{18} \mathrm{O}_{\mathrm{w}}$ values, that contribute to variability of the $\delta^{18} \mathrm{O}_{\mathrm{w}}$ record at Kisangani. In contrast, in the Oubangui more smooth trends were observed, however, despite the strong $\mathrm{Q}-\delta^{18} \mathrm{O}_{\mathrm{w}}$ relationship (Fig. 5), there is approximately a 30 day time shift between the $\delta^{18} \mathrm{O}_{\mathrm{w}}$ values and peak discharge (Fig. 4), which according to Kelemen et al. (2017) is most likely related to local rainfall entering the river and causing a slightly earlier decrease in $\delta^{18} \mathrm{O}_{\mathrm{w}}$ values.

The most likely explanation for the consistently observed correlation between $\mathrm{Q}$ and $\delta^{18} \mathrm{O}_{\mathrm{w}}$ is that both parameters respond primarily to rainfall. As first described by Dansgaard (1964), abundant rain (i.e. a more complete rainout of water vapour) typically results in more ${ }^{18} \mathrm{O}$-depleted precipitation (referred to as the "amount effect"), while during the dry season precipitation tend to be more ${ }^{18} \mathrm{O}$-enriched (Gonfiantini et al., 2001). This effect is indeed visible in the available $\delta^{18} \mathrm{O}$ data for precipitation from Bangui and to a lesser extent, Kisangani (Fig. S6). During the wet season, increased rainfall causes an increase in river discharge and contributes ${ }^{18} \mathrm{O}$-depleted water. When river water levels decrease during the dry season, the residence time increases thereby enhancing evaporation (Fig. S7) and exchange with atmospheric water vapor, coupled with higher $\delta^{18} \mathrm{O}$ precipitation from the amount effect (Fig. S6) leading to a gradual enrichment in ${ }^{18} \mathrm{O}$ of the river water. However, this relationship may not be as pronounced in rivers draining dense rainforest. During low water conditions the vegetation cover determines the level of evaporation. In dense rainforest transpiration dominates, which is a non-fractionating process (White et al., 1985; Gat, 1996), thus only a mild ${ }^{18} \mathrm{O}$-enrichment is expected. In contrast, rivers passing savannahs (such as the Oubangui) without a protective forest cover and due to lower humidity are more prone to evaporation and carry more ${ }^{18} \mathrm{O}$-enriched water (Fig. S7). Other studies have also reported river channel evaporative ${ }^{18} \mathrm{O}$ enrichment, such as Gremillion and Wanielista (2000) who studied a subtropical watershed in central Florida, USA.

As can be seen in Fig. 4, there is no systematic relationship between water temperature and $\delta^{18} \mathrm{O}_{\mathrm{w}}$ or between water temperature and $\mathrm{Q}$ at any location, except the Oubangui River. In the latter system, temperature covaries with $\delta^{18} \mathrm{O}_{\mathrm{w}}$. During periods of low discharge, both temperature and $\delta^{18} \mathrm{O}_{\mathrm{w}}$ are at their maximum due to a combination of the amount effect and evaporation (Figs. S6 and S7), which is expected to be significant in this more arid watershed. Conversely, during high $\mathrm{Q}, \delta^{18} \mathrm{O}_{\mathrm{w}}$ values gradually decrease, representing greater runoff of $\delta^{18} \mathrm{O}$-depleted precipitation and less evaporative conditions. At the other three locations, the temperature range is greater than at Bangui, while the $\delta^{18} \mathrm{O}_{\mathrm{w}}$ ranges are lower, but due to large influence of the constant water input from small tributaries and rainfall, the data are more scattered without a consistent relationship between both parameters. 


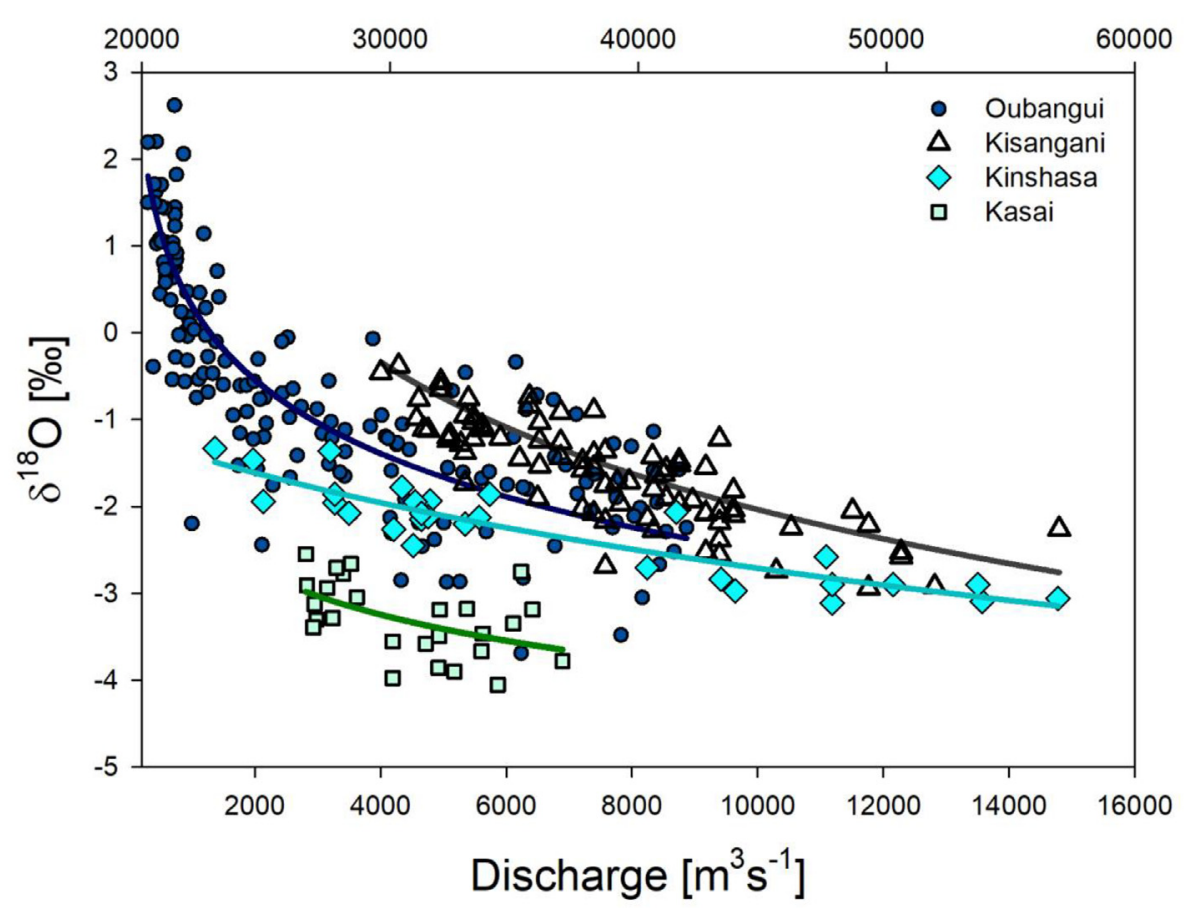

Fig. 5. Correlation between discharge and $\delta^{18} \mathrm{O}_{\mathrm{w}}$ values for the four monitoring location. In the graph discharge for Kinshasa is on the top axis. Regression relationships are: $\delta^{18} \mathrm{O}_{\mathrm{w}}=-1.749 \mathrm{ln}(\mathrm{Q})+13.986\left(\mathrm{R}^{2}=0.59\right)$ for the Congo River at Kisangani, $\delta^{18} \mathrm{O}_{\mathrm{w}}=-1.122 \mathrm{ln}$ $(\mathrm{Q})+7.927\left(\mathrm{R}^{2}=0.71\right)$ for the Oubangui, $\delta^{18} \mathrm{O}_{\mathrm{w}}=-1.82 \ln (\mathrm{Q})+16.787\left(\mathrm{R}^{2}=0.81\right)$ for the Congo River at Kinshasa, and $\delta^{18} \mathrm{O}_{\mathrm{w}}=-0.741 \mathrm{ln}$ $(\mathrm{Q})+2.8973\left(\mathrm{R}^{2}=0.26\right)$ for the Kasai.

These four key sites in the Congo Basin all show consistent seasonality in discharge, but differ strongly in the relative amplitude of discharge variations. These differences can be compared through $\mathrm{Q}_{\max } / \mathrm{Q}_{\min }$ ratios, which were calculated as the average ratio of the 10 consecutive highest daily discharge values to the 10 consecutive lowest daily discharge values for each calendar year during a 6-year period. The $\mathrm{Q}_{\max } / \mathrm{Q}_{\min }$ ratio is the lowest for the main stem Congo River at Kinshasa $\left(Q_{\max } / Q_{\min }=2.2\right.$, for the period 2010 2015) consistent with the Congo River being known as one of the most regular and uniform major rivers on Earth (Laraque et al., 2001; 2020; Coynel et al., 2005; Runge, 2007). Slightly higher discharge ratios were measured at Kisangani $\left(\mathrm{Q}_{\max } / \mathrm{Q}_{\min }=2.5\right.$, between 2012-2017) and in the Kasai River $\left(\mathrm{Q}_{\max } / \mathrm{Q}_{\min }=2.4\right.$; between 2012-2017). The highest discharge ratios were measured in the Oubangui River, where the multi-decadal $\mathrm{Q}_{\max } / \mathrm{Q}_{\min }$ record were rarely below $8\left(\mathrm{Q}_{\max } / \mathrm{Q}_{\min }=14.6\right.$, between $1911-2017$ and 19.2 between $2012-2017$ ), but were as high as 30 . We found low $\mathrm{Q}_{\max } / \mathrm{Q}_{\min }$ ratios to correspond to low amplitude annual $\delta^{18} \mathrm{O}_{\mathrm{w}}$ cyclicity (Fig. 6), and increasing $\mathrm{Q}_{\max } / \mathrm{Q}_{\min }$ ratios to be associated with higher $\delta^{18} \mathrm{O}$ variability. Indeed, the ranges of measured $\delta^{18} \mathrm{O}_{\mathrm{w}}$ values were very low $(1.5 \%$, $1.8 \%$ and $2.6 \%$ ) for Kasai, Congo at Kinshasa and Congo at Kisangani, respectively, in comparison with the Oubangui River, where values range over 6\%o (Kelemen et al., 2017). In Fig. 6, individual yearly $\mathrm{Q}_{\max } / \mathrm{Q}_{\min }$ ratios were compared with $\delta^{18} \mathrm{O}_{\mathrm{w}}$ values for the same time intervals for the rivers in the Congo Basin and a number of additional river sites in Sub-Saharan Africa for which oxygen isotope data and daily discharge data were available.
Although the rivers from the Congo Basin fit a linear regression $\left(\mathrm{R}^{2}=0.91, \mathrm{~N}=13\right)$, individual years show some scatter for both parameters, reflecting the year-to-year variability of different factors (e.g. rainfall, evaporation, groundwater) contributing to river flow. While rivers traversing dense forests (Congo at Kisangani, Congo at Kinshasa, Kasai, Ogooué) show less variability in the relationship between $\mathrm{Q}_{\max } / \mathrm{Q}_{\min }$ and $\delta^{18} \mathrm{O}_{\mathrm{w}}$, rivers draining mainly savannah at higher latitudes (Niger and Oubangui) show larger differences between years, however they show a strong linear relationship $\left(\mathrm{R}^{2}=0.82, \mathrm{~N}=18\right.$, Fig. 6). In rivers influenced by dams (Kafue River upstream of its confluence with the Zambezi River (Zambia), and the Tana River at Garissa, Kenya) due to the shorter or longer residence time of the water, evaporation rate might differ more than in rivers with natural flow, resulting in higher variability of $\delta^{18} \mathrm{O}_{\mathrm{w}}$ values (Fig. 6).

\subsection{Oxygen isotope variation in Congo basin bivalve shells}

Freshwater bivalves are known to precipitate their calcium carbonate shells in oxygen isotopic equilibrium with the host water (Dettman et al., 1999; Goewert et al., 2007; Kelemen et al., 2017; Goodwin et al., 2019). All sampling locations exhibit relatively minor surface water temperature variations $\left(3.3-6.7^{\circ} \mathrm{C}\right)$, thus $\delta^{18} \mathrm{O}_{\mathrm{w}}$ values are expected to have the major control over $\delta^{18} \mathrm{O}_{\text {shell }}$ record (Kelemen et al., 2017). In order to examine if $\delta^{18} \mathrm{O}_{\text {shell }}$ data correspond to $\delta^{18} \mathrm{O}_{\mathrm{w}}$ records, $\delta^{18} \mathrm{O}_{\mathrm{w}}$ values together with the measured temperature data were used to calculate a model shell $\delta^{18} \mathrm{O}$ values (Eqs. (1) and (2)), similar to the 
approach used in previous studies (Klein et al., 1996; Kelemen et al., 2017; Goodwin et al., 2019). Ranges of the model shells are listed in Table 2, and compared to measured values in Figs. 7-8. Considering shells record oxygen isotope ratios in the host water, the range of $\delta^{18} \mathrm{O}_{\text {shell }}$ is expected to be similar to that of $\delta^{18} \mathrm{O}_{\mathrm{w}}$. However, biological factors can alter the direct reflection of the $\delta^{18} \mathrm{O}_{\mathrm{w}}$ values recorded in the shells. Fig. 7 shows data for one example shell from each location compared directly to that of the model shell based on environmental data. They generally illustrate a good match, although the measured range is somewhat smaller than that of the $\delta^{18} \mathrm{O}_{\mathrm{w}}$ record. Two factors are most likely responsible for the lower amplitude in $\delta^{18} \mathrm{O}_{\text {shell }}$ versus $\delta^{18} \mathrm{O}_{\mathrm{w}}$ : (i) growth rate and (ii) sampling resolution. Depending on the rate of shell growth, rapid changes in the water chemistry are not always detected in the shells, as the calcification rate can vary over time, ontogenetically, between species, and between rivers. Bivalves tend to reduce growth over ontogeny (Goodwin et al., 2003). Growth cessations during unfavorable growth conditions (such as high turbidity), can cause temporary growth hiatuses (Kaandorp et al., 2003; Kelemen et al., 2017) during which $\delta^{18} \mathrm{O}_{\mathrm{w}}$ values would not be recorded in the shell. Sampling resolution and thus time averaging is also an important factor which can cause the lower range of recorded $\delta^{18} \mathrm{O}_{\text {shell }}$ values (Goodwin et al., 2003).

\subsection{Species-related differences in $\delta^{18} \mathrm{O}_{\text {shell }}$ variations?}

In order to cope with the heterogeneity and instability of freshwater environments many species adapt their shell shape to environmental conditions (Scholz, 2013). In the current study, all analyzed bivalves are from the Unionoida order. Within the Unionids, shell morphology is highly variable, as reflected in the shell structure of our analyzed species (Fig. 3). Unfortunately, there is no detailed information about the process of shell building of these particular species of Unionids and only a very limited amount of information exist in the literature about their ecology, feeding and reproductive habits,.

Differences in shell structure affects the sampling resolution, which unintentionally leads to time averaging, and could result in lower amplitude $\delta^{18} \mathrm{O}_{\text {shell }}$ profiles. In this study, shells were sectioned and the outer prismatic layer was sampled: however the thickness of this layer was very variable among species. Shell thickness can be speciesspecific, however, individuals from the same species develop adaptively divergent shells to cope with the variability and instability of freshwater ecosystems (lakes, ponds, fast or slow flowing rivers). For example, the Aspatharia sinuata population from the Oyun River (Nigeria) was shown to develop much thicker and heavier shells to withstand the harsh fluvial conditions compared to specimens inhabiting reservoirs (Blay, 1989). Chambardia and Aspatharia species are known for their robust shell structure, which allows a higher level of adaptability, thus these bivalves can thrive even in extreme conditions. According to Scholz (2013), juvenile bivalves of Chambardia nyassaensis from Lake Malawi live deeply buried in the sediment, while grown individuals prefer semi-infaunal lifestyle, only partly buried. The elongated headwater shape allows them to quickly rebury if low water conditions occur, the tolerance to dry conditions explains why this species is abundantly found in both deep and shallow water (Scholz, 2013). Beadle (1974) reported that Aspatharia species can survive up to two years under desiccated conditions. From our analyzed species, Chambardia and Aspatharia shells had the thickest prismatic layers (Fig. 3), which allowed sampling these

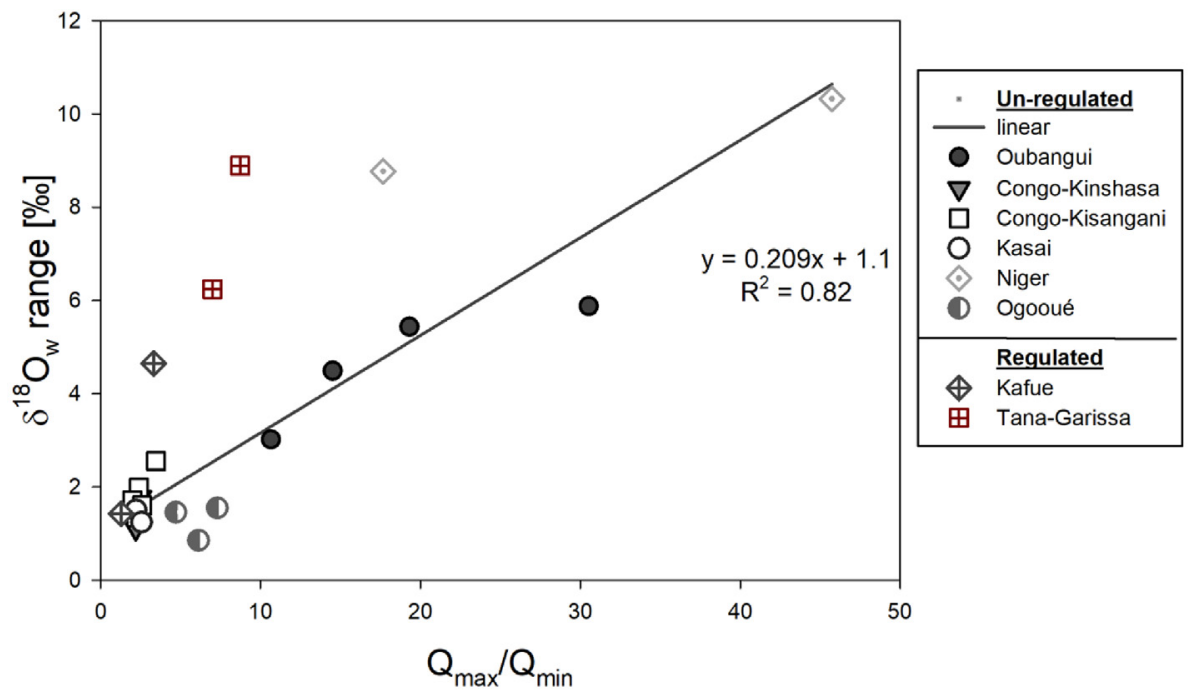

Fig. 6. Yearly $\mathrm{Q}_{\max } / \mathrm{Q}_{\min }$ ratios (x-axis) compared with the range of river $\delta^{18} \mathrm{O}_{\mathrm{w}}$ values (y-axis) for individual years. Various symbols illustrate the relationship for one river but for different years. Years included: Oubangui (2010-2013), Congo - Kinshasa (2011-2012), Congo Kisangani (2013-2017), Kasai (2015-2016), Niger at Niamey (2011-2012), Ogooué at Lambaréné, Gabon (2012-2014), Kafue, Zambia (20122013) and Tana at Garissa (Kenya) (2012-2013). Calculated linear regression includes only the un-regulated rivers $\left(\mathrm{R}^{2}=0.82, \mathrm{~N}=18\right) . \mathrm{Data}$ from the Niger and Oubangui are from Kelemen et al. (2017), Tana-Garissa is from Geeraert (2015), Ogooué from Bouillon et al. (2020) and Kafué data is from Teodoru et al. (2020). 

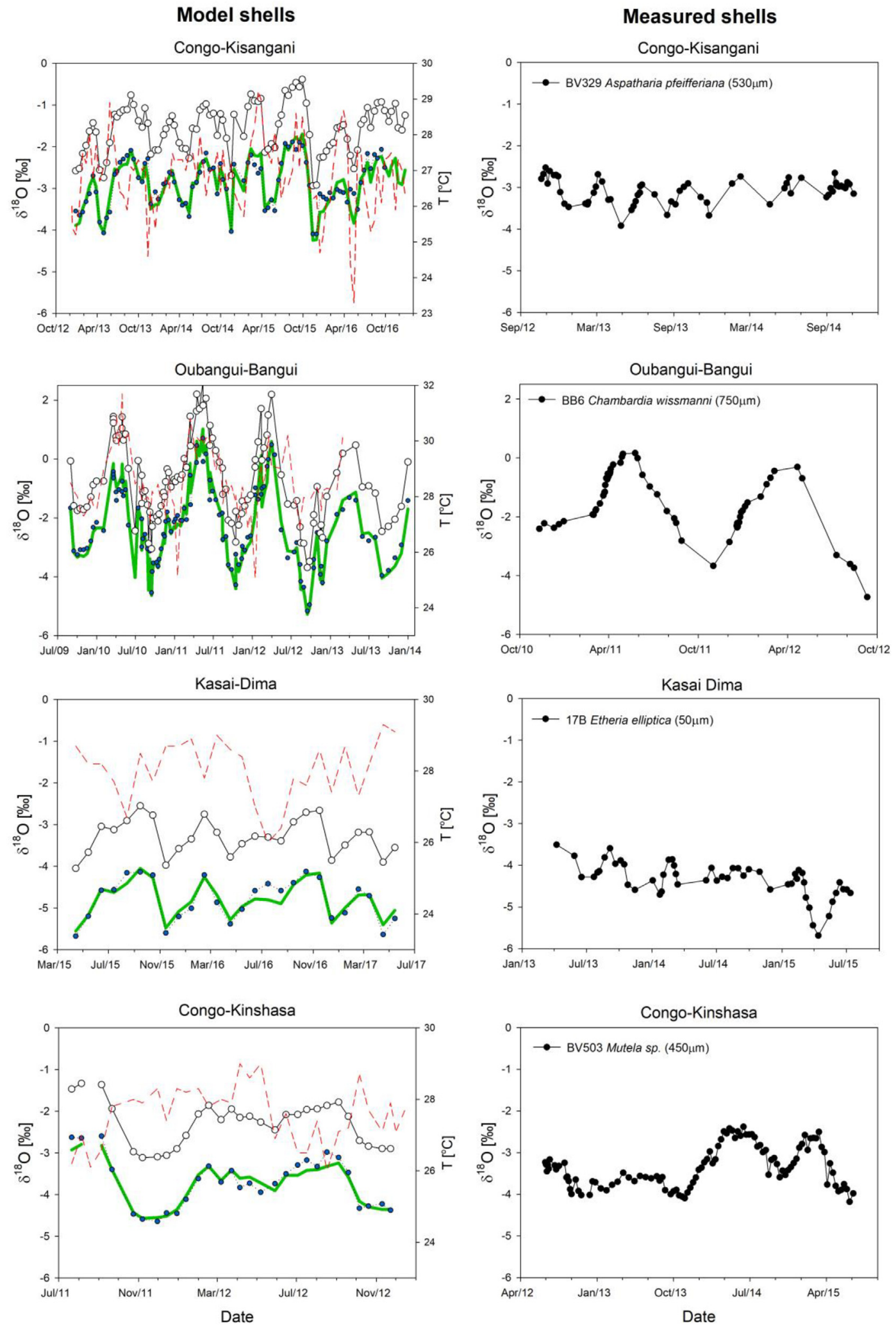

Fig. 7. Contrasting $\delta^{18} \mathrm{O}_{\text {shell }}$ record of each location. Left column shows the $\delta^{18} \mathrm{O}$ values of model shells (filled circles connected with dotted lines) with measured water $\delta^{18} \mathrm{O}$ (open circles) and temperature (dashed lines) values (used for the model shell calculation) for each location. An additional model shell was calculated with average temperature values for each location (green solid line) Right column represents the corresponding $\delta^{18} \mathrm{O}$ record of one example shell for each location, with Date on the $\mathrm{X}$-axis. Shell code, species name, and sampling resolution are also listed. 

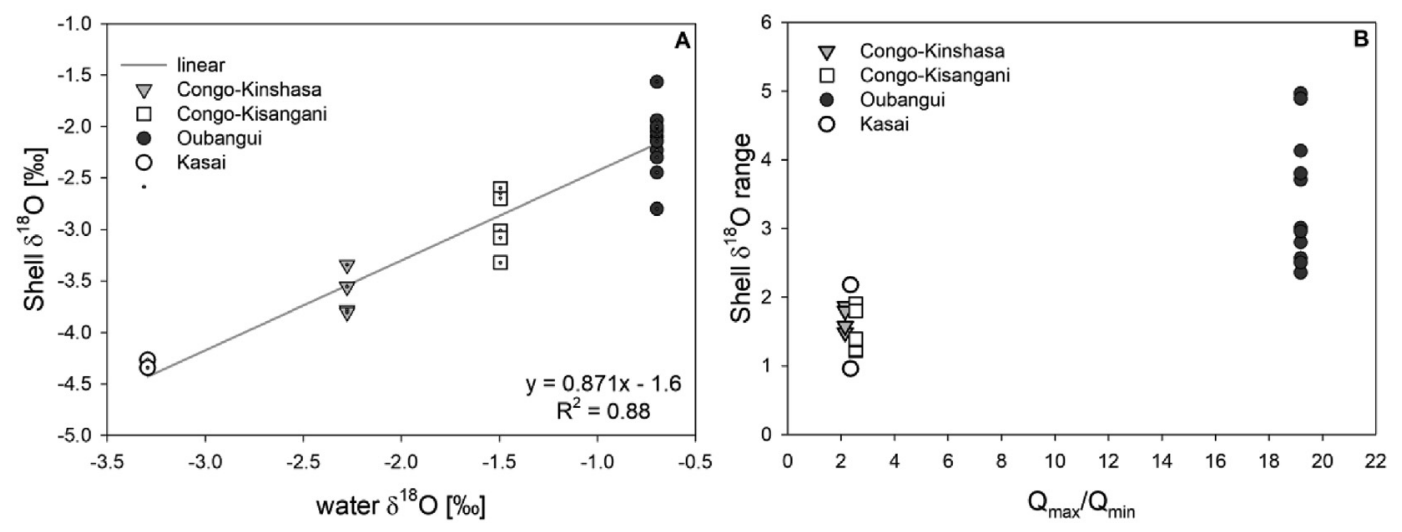

Fig. 8. A) Average $\delta^{18} \mathrm{O}_{\text {shell }}$ values of each freshwater African Unionid versus $\delta^{18} \mathrm{O}_{\mathrm{w}}$ values for each river fit a linear regression curve $\left(\mathrm{R}^{2}=0.88, \mathrm{~N}=23\right)$. B) Individual $\delta^{18} \mathrm{O}_{\text {shell }}$ ranges grouped by locations (various symbols) and plotted with the corresponding $\mathrm{Q}_{\max } / \mathrm{Q}_{\min }$ ratios at each location.

shells with the highest resolution. Indeed, these species were shown to be very reliable proxies for $\delta^{18} \mathrm{O}_{\mathrm{w}}$ variation, as they deposit a large amount of $\mathrm{CaCO}_{3}$, and grow up to $0.75 \mathrm{~mm} \mathrm{day}{ }^{-1}$ in their first years of life (Kelemen et al., 2017). According to study of Blay and Yoloye (1987) juvenile individuals of $A$. sinuata grow rapidly during the first two years of their life, but this declines thereafter. In our study, these two species showed the best correlation with the calculated model shell for each river (Fig. 7). Coelatura shells had a slightly thinner prismatic layer (Fig. 3), which had to be milled along lines (as opposed to drilling spots), to collect a sufficient amount of powder for analysis, which could also lead to differences in time averaging. Finally, the Mutela specimen had a very thin and fragile prismatic layer, making it difficult to sample only the prismatic layer, hence we sampled the shell throughout the inner layer (both layers are aragonite). The thinner shell might be the consequence of the adaptation of the genus Mutela to a continuous infaunal life. This species prefers deeper waters, because the developed posterior gap allows feeding without opening the valves, but makes this species vulnerable to desiccation (Scholz, 2013). However, despite the difference in layers sampled (inner nacreous vs prismatic), the Mutela shell matched the model shell well (Fig. 7). Undoubtedly, Etheria species precipitate the most complex shells in this study (Fig. 3), with a very porous structure and numerous cavities that often result in asymmetrical growth (Van Bocxlaer and Van Damme, 2009). The youngest animals are bilaterally symmetrical, they become asymmetrical after they cement to a hard surface (very often to an another shell) (Yonge, 1962). To the best of our knowledge, only three studies have measured $\delta^{18} \mathrm{O}$ values in Etheria shells (Abell et al., 1996; Rodrigues et al., 2000; Vonhof et al., 2013), and two studies outlined the complexity of these shells for analysis as the numerous voids make it difficult to sample contiguous growth lines close to each other. E. elliptica grows in moving and often turbulent water, 2-3 $\mathrm{m}$ below the surface (Yonge, 1962). Indeed, this species thrives in fast moving water habitat; Akélé et al. (2017) reported that growth rates of adult E. elliptica are the highest during rainy/flood period. E. elliptica is intolerant of salinity and desiccation (Van Damme, 1984), juvenile specimens are especially sen- sitive to siltation (Anthony, 1907) and reach sexual maturity $(\sim 65 \mathrm{~mm})$ in about 22 months (Akélé et al., 2017). This species lives cemented to a hard substrate, which makes it more sensitive to changes in the aquatic environment than other species, which are able to relocate or bury into a soft substrate. Nevertheless, in this study the $\delta^{18} \mathrm{O}_{\text {shell }}$ record of Etheria covered the majority of the model shell range for each location. Thus, despite the morphological variability among the species, all analyzed shell $\delta^{18} \mathrm{O}$ values were synchronized with $\delta^{18} \mathrm{O}_{\mathrm{w}}$ values of the corresponding rivers.

\subsection{Effect of temperature on shell isotope values}

Kelemen et al. (2017) compared the effect of temperature on reconstructed $\delta^{18} \mathrm{O}_{\mathrm{w}}$ values from the $\delta^{18} \mathrm{O}_{\text {shell }}$ record and concluded that in these tropical regions, temperature variations play a relatively small role in $\delta^{18} \mathrm{O}_{\text {shell }}$ values, for example $1{ }^{\circ} \mathrm{C}$ difference in water temperature results in $\sim 0.19 \%$ change in calculated $\delta^{18} \mathrm{O}$ values. While in situ temperature data were available for our sites, the question of temperature dependency of oxygen isotope fractionation is relevant when considering the use of historical shell specimens, or shells from sites where no temperature data are available. While we have shown that the effect of temperature is a relatively minor concern in systems such as the Oubangui or Niger, where there is a strong seasonal amplitude in $\delta^{18} \mathrm{O}_{\mathrm{w}}$ and little variability in water temperature (Kelemen et al., 2017), this would become more important in sites where seasonality in discharge, and hence $\delta^{18} \mathrm{O}_{\mathrm{w}}$ variations, are more modest. To test the potential influence of temperature in our isotopic record, an additional "model shell" was calculated assuming average temperatures for the study sites. Comparing the two model shells (Fig. 7), only a negligible variation could be observed at all sites, confirming the small influence of temperature on $\delta^{18} \mathrm{O}_{\text {shell }}$ record in these tropical conditions.

\section{5. $\delta^{18} \mathrm{O}_{\text {shell }}$ values as a hydrologic proxy}

While some measured individual $\delta^{18} \mathrm{O}_{\text {shell }}$ records do not fully match the ranges of predicted $\delta^{18} \mathrm{O}_{\text {shell }}$ values, the 
average measured $\delta^{18} \mathrm{O}_{\text {shell }}$ values correspond very well (Fig. 8A). Average values of individual shells exhibit a strong linear relationship with average $\delta^{18} \mathrm{O}_{\mathrm{w}}$ values $\left(\mathrm{R}^{2}=0.88\right)$, which further illustrates that $\delta^{18} \mathrm{O}_{\mathrm{w}}$ values are reliably recorded by the shells. Individual shell average values show some scatter, which is likely related to time averaging or shell cessation as discussed above. Furthermore, it should be kept in mind that $\delta^{18} \mathrm{O}_{\mathrm{w}}$ data were typically collected at 2-weekly intervals which could miss some variability, and the resolution of shell data has some variability. Similar to this approach, Kohn and Dettman (2007) showed average riverine $\delta^{18} \mathrm{O}_{\mathrm{w}}$ values correlated well with bulk shell $\delta^{18} \mathrm{O}$ values across the United States $\left(\mathrm{R}^{2}=0.98\right)$, their relationship is analogous to that shown in Fig. 8A with an offset explained by the generally lower temperatures in their study. A more recent study compiled mean $\delta^{18} \mathrm{O}_{\text {shell }}$ values of 28 freshwater mollusk species from 25 river basins globally and showed that shell oxygen isotopes can be used as a proxy for river water $\delta^{18} \mathrm{O}_{\mathrm{w}}$ composition (Pfister et al., 2019), but ours is the first study attempting this within a large tropical river basin. When average shell values are used, short-term variations in $\delta^{18} \mathrm{O}_{\mathrm{w}}$ composition cannot be observed, however average $\delta^{18} \mathrm{O}_{\text {shell }}$ values are still suitable to record long-term changes in $\delta^{18} \mathrm{O}_{\mathrm{w}}$.

As expected, bivalve specimens had a very similar $\delta^{18} \mathrm{O}_{\text {shell }}$ range to model shells. However, $\delta^{18} \mathrm{O}_{\text {shell }}$ values did not reach the full amplitude of the model shells, which can be attributed to individual growth characteristics of each specimen. When including all shells per site, the $\delta^{18} \mathrm{O}_{\text {shell }}$ range is very closely reflected in the range of $\delta^{18} \mathrm{O}_{\mathrm{w}}$ values. Thus, shell oxygen isotope records reflect the $\mathrm{Q}_{\max } / \mathrm{Q}_{\min }$ ratios at these locations (Fig. 8B), but shells from sites with intermediate $\mathrm{Q}_{\max } / \mathrm{Q}_{\min }$ ratios are needed to assess the robustness of this relationship. However, considering these bivalve shells record seasonal variations of $\delta^{18} \mathrm{O}_{\mathrm{w}}$ values, we expect the relationship between the range of $\delta^{18} \mathrm{O}_{\text {shell }}$ values and the $\mathrm{Q}_{\max } / \mathrm{Q}_{\min }$ ratio to hold true in regions where seasonal changes in $\mathrm{Q}$ result in predictable $\delta^{18} \mathrm{O}_{\mathrm{w}}$ differences. Both the ability of shells to record riverine $\delta^{18} \mathrm{O}_{\mathrm{w}}$ values and provide an indication of discharge variability $\left(Q_{\max } / \mathrm{Q}_{\min }\right.$ ratios) make freshwater African Unionids promising for paleo-riverine and paleo-climate reconstruction in the present and past using both museum archived shells as well as fossils.

\section{CONCLUSIONS}

Results from this study show that the seven species of African Unionid freshwater bivalves precipitate their shells in oxygen isotope equilibrium with the water they inhabit. All specimens recorded seasonal $\delta^{18} \mathrm{O}_{\mathrm{w}}$ variations, although to a varying extent. Average $\delta^{18} \mathrm{O}_{\text {shell }}$ records showed a very good correlation with $\delta^{18} \mathrm{O}_{\mathrm{w}}$ values at all four locations in the Congo Basin. Limitations regarding $\delta^{18} \mathrm{O}_{\text {shell }}$ ranges covered by individual specimens can be prevented by analyzing multiple shells at each location. However, for high temporal resolution sampling, species which precipitate robust shells and grow fast as the Aspatharia and Chambardia have shown to be the most suitable.
Following a successful demonstration of the potential of freshwater bivalve shell $\delta^{18} \mathrm{O}$ values in reconstructing discharge variations when a robust relationship exists between $\delta^{18} \mathrm{O}_{\mathrm{w}}$ and discharge as in the Oubangui River (Kelemen et al., 2017), this study evaluated to what extent this can be extrapolated to other sites within the Congo River basin. We found that the range in $\delta^{18} \mathrm{O}_{\mathrm{w}}$ (and hence, $\delta^{18} \mathrm{O}_{\text {shell }}$ ) is lower in systems where the amplitude of seasonal variability in discharge (expressed as the $\mathrm{Q}_{\max } / \mathrm{Q}_{\min }$ ratio) is low, and high when $\mathrm{Q}_{\max } / \mathrm{Q}_{\min }$ is high. Thus shells have a high potential to produce historical and fossil records of seasonality in discharge and longer-term changes in river hydrology. Long-term changes in precipitation sources, average discharge, discharge variability $\left(\mathrm{Q}_{\max } / \mathrm{Q}_{\min }\right.$ ratio), and possibly effects of land-use change (such as deforestation, which modifies water routing pathways) or human disturbance (e.g. dam construction - which leads to evaporation and flow regulation) are expected to be reflected in shell proxies. Analyzing shells from different time periods from such basins would be of particular interest (e.g., museum archived or fossil shells). Indeed, $\mathrm{Q}_{\max } / \mathrm{Q}_{\min }$ may change through time, which could be tracked using shells. Thus, African Unionids are suitable for paleo-riverine and paleo-climate reconstruction in the present and past using both museum archived shells as well as fossils.

The same general conclusion is likely to hold true on a much larger spatial scale: while we examined only river systems in (sub)tropical regions of Africa that are often characterized by distinct wet and dry seasons, rivers in other parts of the world often lack distinct relationships between discharge and $\delta^{18} \mathrm{O}_{\mathrm{w}}$ due to more complex water source contributions at high latitudes (e.g. Fan and Dettman, 2009; Yi et al., 2012). Thus, the type of information that can be derived from measuring stable isotope proxies in freshwater in river systems is strongly site-dependent.

\section{Declaration of Competing Interest}

The authors declare that they have no known competing financial interests or personal relationships that could have appeared to influence the work reported in this paper.

\section{ACKNOWLEDGEMENTS}

We thank Victoria Springer and Nathalie Carlier for contributing with shell analyses in the framework of their MSc theses. We thank Dan Graf for identifying the shell specimens and for his work on the MusselP database (http://mussel-project.uwsp.edu), and Thibault Lambert for producing Fig. 1. We are thankful to Gil Mahé, Julien Thébault, Nicole Van Lipzig and Robert Speijer as well as to Ethan Grossman, two anonymous reviewers, and Claire Rollion-Bard (editor) for valuable comments on earlier versions of this manuscript. We are grateful to the Isotope Hydrology Laboratory of the International Atomic Energy Agency (IAEA) for analyses of water stable isotope ratios which contribute to the Coordinated Research Project CRPF33021 (Application and development of isotope techniques to evaluate human impacts on water balance and nutrient dynamics of large river basins) implemented by 
the International Atomic Energy Agency (IAEA). Funding for this study was provided by the European Research Council (ERC Starting Grant StG 240002, AFRIVAL) to S.B. and A.V.B., a National Geographic Society Research and Exploration Grant (\#8885-11) to D.P.G. and S.B., the KU Leuven Special Research Fund (DBOF PhD scholarship to Z.K.), the Research Foundation Flanders (FWOVlaanderen; research project G.0D87.14 N, and travel grants) to S.B. and D.P.G., the Belgian Federal Science Policy (BELSPO, 'COBAFISH' project SD/AR/05A) and a Research Corporation for Science Advancement, SingleInvestigator Cottrell College Science Award (\#20169) to D.P.G. The US National Science Foundation funded Union College's isotope ratio mass spectrometer and peripherals (NSF-MRI \#1229258). A.V.B. is a research director at the Fonds National de la Recherche Scientifique (FNRS).

\section{DATA AVAILABILITY}

All data underlying the manuscript are provided as an electronic supplement.

\section{APPENDIX A. SUPPLEMENTARY MATERIAL}

Supplementary data to this article can be found online at https://doi.org/10.1016/j.gca.2021.05.023.

\section{REFERENCES}

Abell P. I., Amegashitsi L. and Ochumba P. B. (1995) The shells of Etheria elliptica as recorders of seasonality at Lake Victoria. Palaeogeogr. Palaeoclimatol. Palaeoecol. 119, 215-219.

Akélé G. D., Montcho S. A. and Lalèyè P. A. (2017) Growth of freshwater Etheria elliptica oyster (Lamarck, 1807) reared in cages in the Pendjari River (Benin, West Africa). Aquat. Living Resour. 30, 17.

Alsdorf D., Beighley E., Laraque A., Lee H., Tshimanga R., O’Loughlin F., Mahé G., Dinga B., Moukandi G. and Spencer R. G. (2016) Opportunities for hydrologic research in the Congo Basin. Rev. Geophys. 54, 378-409.

Anthony R. (1907) Etude monographique des Aetheriidae (Anatomie, Morphogénie, Systématique). Ann. Soc. Zool. Malac. Belg. 41, 322-430.

Beadle L. C. (1974). The Inland Waters of Tropical Africa: An Introduction to Tropical Limnology. Longman, London.

Blay, Jr, J. (1989) Morphometry, length-weight relationships and length distributions of five populations of the freshwater bivalve Aspatharia sinuata (Unionacea, Mutelidae) in Nigeria. Malacologia 30(1-2), 365-372.

Blay J. and Yoloye V. (1987) Observations on the growth of some populations of the freshwater bivalve Aspatharia sinuata (Unionacea, Mutelidae) in Nigeria. Korean J. Zool. 30(2), $140-153$.

Borges A. V., Darchambeau F., Teodoru C. R., Marwick T. R., Tamooh F., Geeraert N., Omengo F. O., Guérin F., Lambert T., Morana C., Okuku E. and Bouillon S. (2015) Globally significant greenhouse gas emissions from African inland waters. Nat. Geosci. 8, 637-642.

Borges A., Darchambeau F., Lambert T., Morana C., Allen G. H., Tambwe E., Sembaito A. T., Mambo T., Wabakhangazi J. N., Descy J. P., Teodoru C. R. and Bouillon S. (2019) Variations in dissolved greenhouse gases $\left(\mathrm{CO}_{2}, \mathrm{CH}_{4}, \mathrm{~N}_{2} \mathrm{O}\right)$ in the Congo River network overwhelmingly driven by fluvial-wetland connectivity. Biogeosciences 16, 3801-3834.

Bouillon S., Darchambeau F., Mbega J. D. and Borges A. V. (2020) Water stable isotope data for the Ogooué River (Gabon) at Lambaréné, 2012-2014.

Bouillon S., Gillikin D. P., Yambélé A., Teodoru C., Darchambeau F., Lambert T. and Borges A. V. (2014) Contrasting biogeochemical characteristics of the Oubangui River and tributaries (Congo River basin). Sci. Rep. 4, 5402.

Bouillon S., Yambélé A., Spencer R. G. M., Gillikin D. P., Hernes P. J., Six J., Merckx R. and Borges A. V. (2012) Organic matter sources, fluxes and greenhouse gas exchange in the Oubangui River (Congo River basin). Biogeosciences 9, 2045-2062.

Brunner P., Therrien R., Renard P., Simmons C. T. and Franssen H. J. H. (2017) Advances in understanding river-groundwater interactions. Rev. Geophys. 55, 818-854.

Bultot F. (1971) Atlas climatique du bassin congolais. [Bruxelles]. .

Calléde J, Boulvert Y, and Thiebaux J. P. (2010). Monographie du Bassin de l'Oubangui. Editions ORSTOM, Collection Monographies Hydrologiques. Available from: www.mpl.ird.fr/hydrologie/document/monogras/oubangui/index104.htm

Coplen T. B. (1988) Normalization of oxygen and hydrogen isotope data. Chem. Geol. (Isotope Geoscience Section) 72, 293 297.

Coplen T. B. and Wassenaar L. I. (2015) LIMS for Lasers 2015 for achieving long-term accuracy and precision of $\delta^{2} \mathrm{H}, \delta^{17} \mathrm{O}$, and $\delta^{18} \mathrm{O}$ of waters using laser absorption spectrometry. Rapid Commun. Mass Sp. 29, 2122-2130.

Coynel A., Seyler P., Etcheber H., Meybeck M. and Orange D. (2005) Spatial and seasonal dynamics of total suspended sediment and organic carbon species in the Congo River. Global Biogeochem. Cy. 19, GB4019.

Dansgaard W. (1964) Stable isotopes in precipitation. Tellus 16, 436-468.

Dettman D. L., Flessa K. W., Roopnarine P. D., Schöne B. R. and Goodwin D. H. (2004) The use of oxygen isotope variation in shells of estuarine mollusks as a quantitative record of seasonal and annual Colorado River discharge. Geochim. Cosmochim. Acta 68, 1253-1263.

Dettman D. L., Kohn M. J., Quade J., Ryerson F. J., Ojha T. P. and Hamidullah S. (2001) Seasonal stable isotope evidence for a strong Asian monsoon. Geology 29, 31-34.

Dettman D. L. and Lohmann K. C. (2000) Oxygen isotope evidence for high-altitude snow in the Laramide Rocky Mountains of North America during the Late Cretaceous and Paleogene. Geology 28, 243-246.

Dettman D. L., Reische A. K. and Lohmann K. C. (1999) Controls on the stable isotope composition of seasonal growth bands in aragonitic fresh-water bivalves (Unionidae). Geochim. Cosmochim. Acta 63, 1049-1057.

Fan M. and Dettman D. L. (2009) Late Paleocene high Laramide ranges in northeast Wyoming: Oxygen isotope study of ancient river water. Earth Plan. Sci. Lett. 286, 110-121.

Gat J. R. (1996) Oxygen and hydrogen isotopes in the hydrologic cycle. Annu. Rev. Earth Pl. Sci. 24, 225-262.

Geeraert N. (2015) Hydrological impacts on the carbon dynamics of large tropical river systems PhD thesis. KU Leuven, p. 252.

Gillikin D. P. and Bouillon S. (2007) Determination of $\delta^{18} \mathrm{O}$ of water and $\delta^{13} \mathrm{C}$ of dissolved inorganic carbon using a simple modification of an elemental analyzer-isotope ratio mass spectrometer (EA-IRMS): an evaluation. Rapid Comm. Mass Spectrom. 21, 1475-1478.

Goewert A., Surge D., Carpenter S. J. and Downing J. (2007) Oxygen and carbon isotope ratios of Lampsilis cardium (Unionidae) from two streams in agricultural watersheds of 
Iowa, USA. Palaeogeogr. Palaeoclimatol. Palaeoecol. 252, 637648.

Gonfiantini R., Roche M. A., Olivry J. C., Fontes J. C. and Zuppi G. M. (2001) The altitude effect on the isotopic composition of tropical rains. Chem. Geol. 181, 147-167.

Goodwin D. H., Gillikin D. P., Banker R., Watters G. T., Dettman D. L. and Romanek C. S. (2019) Reconstructing intra-annual growth of freshwater mussels using oxygen isotopes. Chem. Geol. 526, 7-22.

Goodwin D. H., Schöne B. R. and Dettman D. L. (2003) Resolution and fidelity of oxygen isotopes as paleotemperature proxies in bivalve mollusk shells : models and observations. Palaios 18, 110-125.

Gorski G., Strong C., Good S. P., Bares R., Ehleringer J. R. and Bowen G. J. (2015) Vapor hydrogen and oxygen isotopes reflect water of combustion in the urban atmosphere. Proc. Natl. Acad. Sci. U S A 112, 3247-3252.

Graf D. L. and Cummings K. S. (2006) Palaeoheterodont diversity (Mollusca: Trigonoida + Unionoida): what we know and what we wish we knew about freshwater mussel evolution. Zool. J. Linn. Soc. 148, 343-394.

Gremillion P. and Wanielista M. (2000) Effects of evaporative enrichment on the stable isotope hydrology of a central Florida (USA) river. Hydrol. Proc. 14, 1465-1484.

Grossman E. L. and Ku T.-L. (1986) Oxygen and carbon isotope fractionation in biogenic aragonite: Temperature effects. Chem. Geol. Isot. Geosci. Sect. 59, 59-74.

Henchiri S., Gaillardet J., Dellinger M., Bouchez J. and Spencer R. G. M. (2016) Temporal variations of riverine dissolved lithium isotopic signatures unveil contrasting weathering regimes in low-relief Central Africa. Geophys. Res. Lett. 43, 4391-4399.

Hughes R. H. and Hughes J. S. (1992). A directory of African wetlands. IUCN.

Jameel Y., Brewer S., Good S. P., Tipple B. J., Ehleringer J. R. and Bowen G. J. (2016) Tap water isotope ratios reflect urban water system structure and dynamics across a semiarid metropolitan area. Water Resour. Res. 52, 5891-5910.

Kaandorp R. J. G., Vonhof H. B., Del Busto C., Wesselingh F. P., Ganssen G. M., Marmól A. E., Romero Pittman L. and Van Hinte J. E. (2003) Seasonal stable isotope variations of the modern Amazonian freshwater bivalve Anodontites trapesialis. Palaeogeogr. Palaeoclimatol. Palaeoecol. 194, 339-354.

Kaandorp R. J. G., Vonhof H. B., Wesselingh F. P., Pittman L. R., Kroon D. and Van Hinte J. E. (2005) Seasonal Amazonian rainfall variation in the Miocene climate optimum. Palaeogeogr. Palaeoclimatol. Palaeoecol. 221, 1-6.

Kelemen Z., Gillikin D. P., Graniero L. E., Havel H., Darchambeau F., Borges A. V., Yambélé A., Bassirou A. and Bouillon S. (2017) Calibration of hydroclimate proxies in freshwater bivalve shells from Central and West Africa. Geochim. Cosmochim. Acta 208.

Klein R. T., Lohmann K. C. and Thayer C. W. (1996) Bivalve skeletons record sea-surface temperature and $\delta^{18} \mathrm{O}$ via $\mathrm{Mg} / \mathrm{Ca}$ and 18O/16O ratios. Geology 24, 415-418.

Kohn M. J. and Dettman D. L. (2007) Paleoaltimetry from stable isotope compositions of fossils. Rev. Mineral. Geochem. 66, $119-154$.

Kumar A., Sanyal P. and Agrawal S. (2019) Spatial distribution of $\delta^{18} \mathrm{O}$ values of water in the Ganga river basin: Insight into the hydrological processes. J. Hydrol. 571, 225-234.

Lambert T., Bouillon S., Darchambeau F., Massicotte P. and Borges A. V. (2016) Shift in the chemical composition of dissolved organic matter in the Congo River network. Biogeosciences 13, 5405-5420.
Laraque A., Mahé G., Orange D. and Marieu B. (2001) Spatiotemporal variations in hydrological regimes within Central Africa during the XXth century. J. Hydrol. 245, 104-117.

Laraque A., Bricquet J. P., Pandi A. and Olivry J. C. (2009) A review of material transport by the Congo River and its tributaries. Hydrol. Process. 23(22), 3216-3224.

Laraque A., Moukandi N'kaya G. D., Orange D., Tshimanga R., Tshitenge J. M., Mahé G., Nguimale C. R., Trigg M. A., Yepez S. and Gulemvuga G. (2020) Recent budget of hydroclimatology and hydrosedimentology of the Congo River in Central Africa. Water 12, 2613.

Lawrence D. and Vandecar K. (2015) Effects of tropical deforestation on climate and agriculture. Nature Clim. Change 5, 2736.

Mariotti A., Francois G., Giresse P. and Mouzeo K. (1991) Carbon isotope composition and geochemistry of particulate organic matter in the Congo River (Central Africa): Application to the study of Quaternary sediments off the mouth of the river. Chem. Geol. 86, 345-357.

Mook W. and Rozanski K. (2000) Environmental isotopes in the hydrological cycle. IAEA and UNESCO, Tech. doc. Hy. 39.

Nicholson S. E. (2000) The nature of rainfall variability over Africa on time scales of decades to millenia. Glob. Planet. Change 26, $137-158$.

Pfister L., Grave C., Beisel J. N. and McDonnell J. J. (2019) A global assessment of freshwater mollusk shell oxygen isotope signatures and their relation to precipitation and stream water. Sci. Rep. 9, 1-6.

Rodrigues D., Abell P. I. and Kröpelin S. (2000) Seasonality in the early Holocene climate of Northwest Sudan: Interpretation of Etheria elliptica shell isotopic data. Glob. Planet. Change 26, 181-187.

Runge J. (2007) The Congo River, Central Africa. Large Rivers Geomorphol. Manag., 293-309.

Teodoru C., Bouillon S., Nyoni F., Nyambe I., and Borges A. V. (2020) Water stable isotope data for the Kafué River (Zambia), 2012-2013. doi: 10.5281/zenodo.4319569.

Scholz H. (2013) Disparity pattern of unionoid bivalves from Lake Malawi (East-Africa): a case study for adaptive strategies to heterogeneous environment. Zoosyst. Evol. 89, 215-225.

Spencer R. G. M., Stubbins A. and Gaillardet J. (2013) Geochemistry of the Congo River, estuary and plume. In Biogeochemical Dynamics at Large River-Coastal Interfaces: Linkages with Global Climate Change (eds. T. S. Bianchi, M. A. Allison and W. J. Cai). Camb. Univ. Press.

Van Bocxlaer B. and van Damme D. (2009) Palaeobiology and evolution of the Late Cenozoic freshwater molluscs of the Turkana Basin: Iridinidae Swainson, 1840 and Etheriidae Deshayes, 1830 (Bivalvia: Etherioidea). J. Sys. Palaeontol. 7, 129-161.

Van Damme D. (1984) The Freshwater Mollusca of Northern Africa: Distribution Biogeography and Paleoecology. Boston 164.

Versteegh E. A. A., Vonhof H. B., Troelstra S. R. and Kroon D. (2011) Can shells of freshwater mussels (Unionidae) be used to estimate low summer discharge of rivers and associated droughts?. Int. J. Earth Sci. 100, 1423-1432.

Vonhof H. B., Joordens J. C. A., Noback M. L., van der Lubbe J. H. J. L., Feibel C. S. and Kroon D. (2013) Environmental and climatic control on seasonal stable isotope variation of freshwater molluscan bivalves in the Turkana Basin (Kenya). Palaeogeogr. Palaeoclimatol. Palaeoecol. 383, 16-26.

Wang Z. A., Bienvenu D. J., Mann P. J., Hoering K. A., Poulsen J. R., Spencer R. G. M. and Holmes R. M. (2013) Inorganic carbon speciation and fluxes in the Congo River. Geophys. Res. Lett. 40, 511-516. 
Wassenaar L. I., Coplen T. B. and Aggarwal P. K. (2014) Approaches for achieving long-term accuracy and precision of $\delta^{18} \mathrm{O}$ and $\delta^{2} \mathrm{H}$ for waters analyzed using laser absorption spectrometers. Environ. Sci. Technol. 48, 1123-1131.

White J. W., Cook E. R. and Lawrence J. R. (1985) The DH ratios of sap in trees: Implications for water sources and tree ring DH ratios. Geochim. Cosmochim. Acta 49, 237-246.

Yi Y., Gibson J. J., Cooper L. W., Hélie J.-F., Birks S. J., McClelland J. W., Holmes R. M. and Peterson B. J. (2012)
Isotopic signals $\left({ }^{18} \mathrm{O},{ }^{2} \mathrm{H},{ }^{3} \mathrm{H}\right)$ of six major rivers draining the pan-Arctic watershed. Global Biogeochem. Cycles 26, GB1027.

Yonge C. M. (1962) On Etheria elliptica Lam. and the course of evolution, including the assumption of monomyarianism in the family Etheriidae (Bivalvia: Unionacea). Philos. Trans. R. Soc. $B$ 244, 423-458.

Associate editor: Claire Rollion-Bard 